\title{
Regulation of Muscarinic Receptors in Hippocampus Following Cholinergic Denervation and Reinnervation by Septal and Striatal Transplants
}

\author{
Jeffrey N. Joyce, ${ }^{1}$ Robert B. Gibbs, ${ }^{2}$ Carl W. Cotman, ${ }^{3}$ and John F. Marshall ${ }^{3}$ \\ 'Department of Pharmacology, University of Pennsylvania School of Medicine, Philadelphia, Pennsylvania 19104 \\ ${ }^{2}$ Neurobiology and Behavior Laboratory, Rockefeller University, New York, New York 10021, and ${ }^{3}$ Department of \\ Psychobiology, University of California, Irvine, California 92717
}

The regulation of hippocampal muscarinic M1 and M2 receptors was studied by autoradiographic methods following cholinergic denervation and reinnervation from embryonic septal transplant. In young adult male rats the density of M1 sites, labeled either with ${ }^{3} \mathrm{H}$-pirenzepine (PZ) or ${ }^{3} \mathrm{H}-\mathrm{N}$-methylscopolamine (NMS, in the presence of excess carbachol), exceeded by 4- to 5-fold the density of M2 sites, labeled with ${ }^{3} \mathrm{H}-\mathrm{NMS}$ in the presence of excess PZ. Both receptors appeared to be densest in hippocampal regions lowest in acetylcholinesterase or ${ }^{3} \mathrm{H}-h$ emicholinium-3 binding. The distribution of $\mathrm{M} 1$ receptors did differ from the distribution of $\mathrm{M} 2$ receptors within subregions of the hippocampus. Along the mediolateral axis from the subiculum to the lateral CA1, the density of $\mathrm{M} 1$ receptors is uniform, but the density of M2 receptors decreases. Also apparent is the relatively small difference in density between the CA1 and dentate gyrus for $M 1$ receptors but a significantly greater difference for M2 receptors. However, the response of M1 and M2 receptors to long-term cholinergic denervation following fimbriafornix transection of the septal cholinergic input and to cholinergic innervation by embryonic septal transplants was similar. Long-term denervation (40-60 d) resulted in a 30$60 \%$ increase in both $M 1$ and $M 2$ receptors within regions of the hippocampal formation. Receptor levels were reduced to normal in regions innervated by septal transplants. For both receptors, the changes in the density of sites were due to alterations in the $B_{\max }$ and not the $K_{d}$ for the radioligands. The specificity of this regulation is supported by the evidence that (1) the degree and topography of the normalization of muscarinic receptor density was entirely dependent on the degree and pattern of cholinergic reinnervation by the fibers of the septal transplant, (2) cholinergic fiber reinnervation by embryonic striatal grafts also down-regulated the density of $M 1$ and $M 2$ receptors, and (3) successfully surviving transplants (e.g., cerebellar and striatal) that

\footnotetext{
Received Aug. 5, 1988; revised Jan. 31, 1989; accepted Feb. 1, 1989.

Research was supported by a grant from the American Federation of Aging Research to J.N.J. and grants NS 20122, NS 22698, and AG 00538 to J.F.M. Some of this work was completed while J.N.J. was supported by NRSA Fellowship NS 07674.

Correspondence should be addressed to J. N. Joyce, Department of Pharmacology/G3, University of Pennsylvania School of Medicine, Philadelphia, PA 19104-6084.

Copyright (C) 1989 Society for Neuroscience $0270-6474 / 89 / 082776-16 \$ 02.00 / 0$
}

did not provide innervation to the hippocampus did not induce down-regulation of muscarinic receptors. Changes in the density of sites were not related to changes in the width of the hippocampus following denervation and reinnervation. The data support the view that the majority of M1 and M2 receptors are located postsynaptically on neurons within the hippocampus and not presynaptically on cholinergic fibers.

Biochemical and behavioral studies indicate that the sensitivity of systems mediated by muscarinic acetylcholine (ACh) receptors respond to the level of neurotransmitter activity. Thus, chronic treatment with muscarinic antagonists results in impaired performance on memory tasks, and tolerance develops following initial exposures to the drug (Kasckow et al., 1984; Messer et al., 1987). A molecular basis for this phenomenon was suggested by the evidence that muscarinic receptor levels can be regulated by their own activity and that this regulation appears to be by a negative-feedback process. Thus, the administration of drugs that enhance receptor activity decrease receptor concentration (Gazit et al., 1979; Ehlert et al., 1980; McKinney and Coyle, 1982), whereas pharmacological blockade of receptors increases receptor levels (Ben-Barak and Dudai, 1980; McKinney and Coyle, 1982; Sutin et al., 1986). Similarly, cholinergic denervation should lead to an increase in muscarinic receptor density (Westlind et al., 1981; McKinney and Coyle, 1982); however, the majority of studies have found no evidence for this effect in the brain (Yamamura and Snyder, 1974; Overstreet et al., 1980; Kamiya et al., 1981; Mash et al., 1985; Watson et al., 1985a; Norman et al., 1986). Furthermore, in the study by McKinney and Coyle (1982), who compared pharmacological treatments and cholinergic denervation, the modest denervation effect was found to be considerably less than that with receptor blockade. The absence of positive results following cholinergic denervation may be due to several possibilities. First, relatively short postoperative periods have been used, which may minimize the possibility of secing the effect. Second, experimental denervation can result in the incomplete loss of cholinergic input to the region of interest. Third, regionally selective changes in receptor density can occur following denervation, which may not be detected by conventional biochemical techniques. Fourth, only a few studies have examined the possibility that muscarinic receptor subtypes could be differentially affected by the deafferentation.

To address the role of cholinergic afferents in the regulation 
of muscarinic receptor subtypes within the brain in more detail, it is useful to have a model that provides for complete deafferentation and subsequent reinnervation. The septohippocampal pathway provides the major source of cholinergic input to the hippocampus (Kasa, 1986). Combined pharmacological and electrophysiological studies have shown that the cholinergic synapse in the normal hippocampus is of the muscarinic type (for review, see Nicoll, 1985). Complete deafferentation of the septohippocampal cholinergic projection system to the dorsal hippocampus can be accomplished with fimbria-fornix transection. Furthermore, reinnervation of the hippocampus can be accomplished by transplantation of embryonic septum into adult host denervated hippocampus. Septal transplants have been shown to reverse behavioral deficits produced by fimbria-fornix transection of the major cholinergic pathway to the hippocampus (Dunnett et al., 1982; Kimble et al., 1986). The transplants form synapses on granule and pyramidal cells which appear to be functionally cholinergic based on biochemical (Bjorklund et al., 1983; Kelly et al., 1985), electrophysiological (Low et al., 1982; Segal et al., 1985), and morphological evidence (Anderson et al., 1986; Clarke et al., 1986). Indirect evidence indicates that the cholinergic input from the grafted embryonic septum establishes muscarinic synapses, since (1) the electrophysiological responses are atropine-sensitive (Segal et al., 1985) and (2) transplant-induced behavioral recovery in aged rats is atropine-sensitive (Gage and Bjorklund, 1986).

Muscarinic receptors have been proposed to be of multiple subtypes based on the evidence that binding of a range of muscarinic agonists to rat cortex follows an isotherm indicative of at least 2, and possibly 3, binding sites (Birdsall et al., 1978), while antagonists normally exhibit characteristics of a 1-site model (Hulme et al., 1978). Subsequent studies utilizing the radioligand ${ }^{3} \mathrm{H}$-pirenzepine (PZ) have shown that this ligand labels 2 sites in brain that do not interconvert (Luthin and Wolfe, 1984; Gil and Wolfe, 1986). It has been proposed that the sites preferentially labeled by $\mathrm{PZ}$ with high affinity be termed the M1 receptor and the site labeled with very low affinity be termed the M2 receptor (see Watson et al., 1983, 1985b, 1986). Both sites have been visualized in the hippocampus using autoradiographic means, and the majority are of the Ml type (Wamsley et al., 1980, 1984; Cortes and Palacios, 1986). It has been proposed that M1 sites are located postsynaptic and M2 sites located presynaptic to cholinergic synapses, based on the differential distribution of $\mathrm{M} 1$ and M2 sites in the brain (Mash and Potter, 1986; Spencer et al., 1986), correlation with acetylcholinesterase (AChE)-positive terminals (Mash and Potter, 1986; Spencer et al., 1986), and loss of sites in cortex after destruction of the nucleus basalis (Mash et al., 1985; Watson et al., 1985a). However, the loss of M2 sites following cholinergic deafferentation of the cortex has not been replicated by others (Norman et al., 1986), and Watson and associates have provided evidence for a presynaptic location for both Ml (Watson et al., 1986) and M2 (Watson et al., 1983) receptors on septohippocampal fibers. The possibility that M1 and/or M2 receptors are located presynaptically on cholinergic fibers suggests that deafferentation-induced loss of presynaptic muscarinic receptors might offset up-regulation of postsynaptically located receptors.

We took advantage of the technique of quantitative autoradiography to examine whether deafferentation of, and subsequent cholinergic reinnervation of, the hippocampus by embryonic septum would result in the regulation of muscarinic M1 and $\mathrm{M} 2$ receptors in the adult host hippocampus.

\section{Materials and Methods}

Animals. Male Sprague-Dawley rats (150-200 gm) received a bilateral knife cut through the fimbria-fornix to remove the native cholinergic innervation of the hippocampus (Anderson et al., 1986). Ten days following the lesion surgery, animals received transplants of embryonic days 16 (E16) or E18 septal tissue, E16 or E18 striatal tissue, or E18 cerebellum placed into the left hippocampus (coordinates: incisor at + 5.0, $3.1 \mathrm{~mm}$ from brcgma, $2.25 \mathrm{~mm}$ lateral, $-3.0 \mathrm{~mm}$ from dura). Transplantation was performed as previously described (Lewis et al., 1980; Lewis and Cotman, 1983; Gibbs et al., 1986). Septal or striatal tissue from one embryo was implanted as a solid graft $\left(1 \mathrm{~mm}^{3}\right)$ into the host recipient. The delay paradigm was used to maximize transplant survival as previously demonstrated (Nieto-Sampedro et al., 1982; Gibbs and Cotman, 1987).

Autoradiographic procedures. Thirty to $50 \mathrm{~d}$ postimplantation, 14 experimental ( 8 septal, 4 striatal, and 2 cerebellar transplanted animals) and 4 control animals were killed and their brains rapidly removed. The brains were immediately frozen in $-20^{\circ} \mathrm{C}$ isopentane for $30 \mathrm{sec}$, then stored at $-80^{\circ} \mathrm{C}$ until processing for autoradiography. For autoradiography, $20-\mu \mathrm{m}$-thick sections were cut at $-14^{\circ} \mathrm{C}$ in a cryostat and thaw-mounted onto gelatin-coated slides. The slide-mounted sections wcre maintaincd at $0-4^{\circ} \mathrm{C}$ while being dried under reduced pressure in a desiccator, then stored at $-80^{\circ} \mathrm{C}$ until the autoradiography assays.

For visualization of the muscarinic M1 receptor, PZ (Wamsley et al., 1984) was used. The distribution of Ml receptors was accomplished by incubating slide-mounted tissue sections in a single concentration (10 $\mathrm{nM})$ of $\mathrm{PZ}\left(K_{d}=25 \mathrm{nM}, 80 \mathrm{Ci} / \mathrm{mmol}\right.$, New England Nuclear). For saturation experiments the concentration range for $\mathrm{PZ}$ was $0.99-198$ nM. Adjacent sections incubated in the presence of $10 \mu \mathrm{M}$ atropine (Sigma) to define nonspecific binding showed no apparent binding. The slide-mounting sections were incubated by layering $3 \mathrm{ml}$ of buffer containing PZ onto the tissue under constant temperature for $1 \mathrm{hr}$ at $20^{\circ} \mathrm{C}$. The incubation solution contained Krebs buffer: $37 \mathrm{~mm} \mathrm{NaCl}, 7 \mathrm{~mm}$ $\mathrm{KCl}, 1.2 \mathrm{~mm} \mathrm{MgCl} \cdot 6 \mathrm{H}_{2} \mathrm{O}, 1.2 \mathrm{mM} \mathrm{NaH} \mathrm{PO}_{4}, 16 \mathrm{~mm} \mathrm{NaHCO}, 1.6$ $\mathrm{mM} \mathrm{CaCl}{ }_{2} \cdot 2 \mathrm{H}_{2} \mathrm{O}, 3.1 \mathrm{~mm}$ glucose. Tissue sections were rinsed for $5 \mathrm{~min}$ in buffer and then dried on a hot plate at $55^{\circ} \mathrm{C}$ after aspiration of excess fluid.

For visualization of the $\mathrm{M} 1$ and $\mathrm{M} 2$ receptors with ${ }^{3} \mathrm{H}-\mathrm{N}$-methylscopolamine ( $\left.{ }^{3} \mathrm{H}-\mathrm{NMS}\right)$, methods described previously were used (Wamsley et al., 1980; Cortes et al., 1986) with minor modifications. For visualization of M1 sites, $1.9 \mathrm{nM}{ }^{3} \mathrm{H}-\mathrm{NMS}$ with $100 \mu \mathrm{M}$ carbachol to block M2 sites and $10 \mu \mathrm{M}$ atropine to define nonspecific binding was used. Muscarinic M2 receptors were labeled with ${ }^{3} \mathrm{H}-\mathrm{NMS}$ in the presence of excess pirenzepine (Boehringer Ingelheim) to block the M1 sites (Cortes et al., 1986). Slide-mounted sections were incubated with 1.9 nM ${ }^{3} \mathrm{H}-\mathrm{NMS}\left(K_{d}=0.4 \mathrm{nM}, 76 \mathrm{Ci} / \mathrm{mmol}\right.$, New England Nuclear) in the presence of $3 \mu \mathrm{M}$ pirenzepine. For saturation experiments the concentration range of ${ }^{3} \mathrm{H}-\mathrm{NMS}$ was $0.012-2.1 \mathrm{nM}$. Adjacent sections incubated in the presence of $10 \mu \mathrm{M}$ atropine to define nonspecific binding showed $<5 \%$ of total binding. Slide-mounted sections were incubated by layering $3 \mathrm{ml}$ of buffer containing ${ }^{3} \mathrm{H}-\mathrm{NMS}$ onto the tissue. Incubations were for $60 \mathrm{~min}$ at $22^{\circ} \mathrm{C}$ in $0.3 \mathrm{M}$ potassium PBS (pH 7.4). Sections were rinsed in sodium phosphate-buffered saline for $10 \mathrm{~min}$ at $0^{\circ} \mathrm{C}$ and then dried on a hot plate at $55^{\circ} \mathrm{C}$ after aspiration of excess fluid.

For visualization of the presynaptic cholinergic terminals, the autoradiographic distribution of ${ }^{3} \mathrm{H}$-hemicholinium-3 ( $\left.{ }^{3} \mathrm{H}-\mathrm{HC}-3\right)$ (Quirion, 1985; Vickroy et al., 1985a, b) or the staining of tissue for AChE reaction product was used. Tissue sections were incubated with $10 \mathrm{nM}{ }^{3} \mathrm{H}-\mathrm{HC}$ $3 ; 120 \mathrm{Ci} / \mathrm{mmol} \mathrm{New} \mathrm{England} \mathrm{Nuclear),} \mathrm{a} \mathrm{concentration} \mathrm{3-4} \mathrm{times} \mathrm{the}$ $K_{d}$ for the high-affinity choline uptake site (Lowenstein and Coyle, 1986), in the presence or absence of $12.5 \mu \mathrm{M} \mathrm{HC}-3$ (Sigma) to define nonspecific binding. Slide-mounted sections were incubated by layering $3 \mathrm{ml}$ of buffer containing ${ }^{3} \mathrm{H}-\mathrm{HC}-3$ onto the tissue. The buffer contained $50 \mathrm{~mm}$ hemiglycylglycinc with $200 \mathrm{~mm} \mathrm{NaCl}(\mathrm{pH} 7.8)$ at $22^{\circ} \mathrm{C}$. Incubation was for $30 \mathrm{~min}$ at $22^{\circ} \mathrm{C}$. Tissue sections were rinsed for $2 \mathrm{~min}$ in buffer, then for $10 \mathrm{sec}$ in double-distilled $\mathrm{H}_{2} \mathrm{O}$ at $4^{\circ} \mathrm{C}$, and dried on a hot plate at $55^{\circ} \mathrm{C}$ after aspiration of excess fluid.

AChE histochemistry was performed according to a modification of the original procedure of Koelle (Koelle and Friedenwald, 1949). The slide-mounted sections were warmed to room temperature and allowed to air-dry. The tissue was then immersed in $10 \%$ buffered formalin for $1 \mathrm{hr}$ and rinsed in doubled-distilled $\mathrm{H}_{2} \mathrm{O}$ for $30 \mathrm{sec}$. Then the slidemounted tissue sections were placed in the incubation solution $(0.1 \mathrm{M}$ $\mathrm{CuSO}_{4}, 0.2 \mathrm{~mm}$ acetylthiocholine iodide, $0.1 \mathrm{~m}$ acetate buffer, $\mathrm{pH}$ 5.3, 

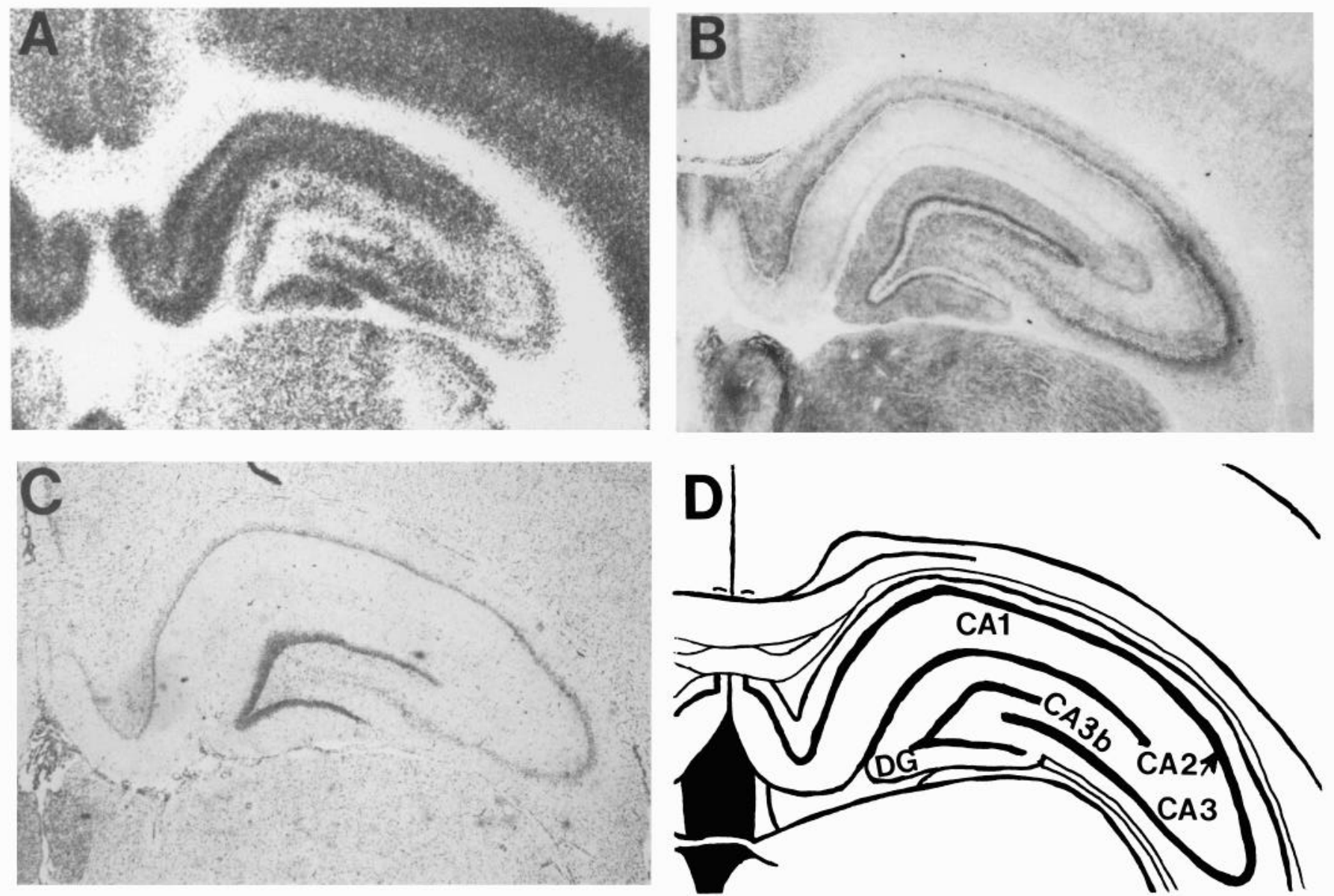

Figure 1. Distribution of M1 receptors $(A)$ and relationship to AChE histochemistry $(B)$ in hippocampus of unoperated control rat. $A$, M1 receptors labeled with ${ }^{3} \mathrm{H}$-pirenzepine at a concentration of $10 \mathrm{nM}$. $B$, AChE histochemistry in adjacent section. $C$, Same section as $A$ but stained for thionin. $D$, Delineation of regions within the hippocampus that were used for autoradiographic analysis of muscarinic receptors. Note the apparent inverse relationship between the density of M1 receptors and AChE-stained cholinergic terminals.

and $\mathrm{CuSO}_{4}$-glycine solution) for $4 \mathrm{hr}$, developed in $3 \% \mathrm{~K}_{3} \mathrm{Fe}(\mathrm{CN})_{6}$, and then rinsed 4 times in doubled-distilled $\mathrm{H}_{2} \mathrm{O}$ for 30 sec each.

Analysis of autoradiographs. After appropriate exposure times, the film was developed in Kodak D-19. For analysis of the autoradiographic images the illuminated image of each autoradiograph was collected by a video camera connected to a Spatial Data Systems Eyecom 850 image analyzer or an IBM AT-based image analysis system (DUMAS, Drexel University, Philadelphia, PA). Because of nonlinearities in the film and image-array processor, these original gray values are not a linear function of the concentration of tritium. By using a standard curve for each piece of film that is generated from tritium-containing standards that are exposed to the film with the experimental tissue sections, the original gray value of each pixel is transformed and expressed as the quantity of radioligand bound. The digitized images of the autoradiographs of total and nonspecific binding were displayed, and a cursor of variable size was positioned over the region of interest to read the density of bound radioligand. Nonspecific binding was subtracted from total binding to obtain the specific binding of each radiogland. The tissue section utilized for the autoradiographic image was stained for cresyl violet or thionin after the development of the autoradiographic images, making them available for visualization of brain structures. The autoradiographic image was viewed in one frame and the stained section viewed in the second frame to assist in quantification of the images. For any radioligand, a minimum of 10 sections at 3 coronal levels along the rostral-caudal axis of the dorsal hippocampus were analyzed for each case. The level of significance for comparison of differences between treatment (lesion or transplant) with control was based on multiple $t$ tests with post hoc correction for multiple comparisons according to the method of Duncan (1955).

\section{Results}

Distribution of cholinergic terminals in control and transplantinnervated hippocampus

In the control (nonlesioned), lesioned, and transplant-innervated hippocampus the distribution of ${ }^{3} \mathrm{H}-\mathrm{HC}-3$ binding sites and staining pattern for $\mathrm{AChE}$ was largely overlapping, suggesting that both techniques are useful markers of cholinergic terminal density. Thus, in the control hippocampus each of the regions (CA1, CA3, dentate gyrus) exhibited a highly laminated patterning for both markers with dense binding or staining of the bands just superficial to the pyramidal or granule cell layer (Figs. $1 B, 2 A)$. However, important distinctions also were apparent in the patterning of the 2 markers. In the control hippocampus, the granule cell layer of the dentate gyrus showed the densest ${ }^{3} \mathrm{H}-\mathrm{HC}-3$ binding with a well-demarcated band (Figs. $2 A, 4$ ). The CA2-CA3 region showed less binding with a more diffuse distribution of label across its width, although the layers immediately surrounding the pyramidal cell layer were still visible as denser bands. The region of $\mathrm{CA} 3 \mathrm{~b}$ was not reduced in density compared with the more lateral CA3. The pyramidal cellular layer of CA 1 was clearly demarcated by a dense band of binding. The oriens layer of CA1 showed more binding than the lacu- 

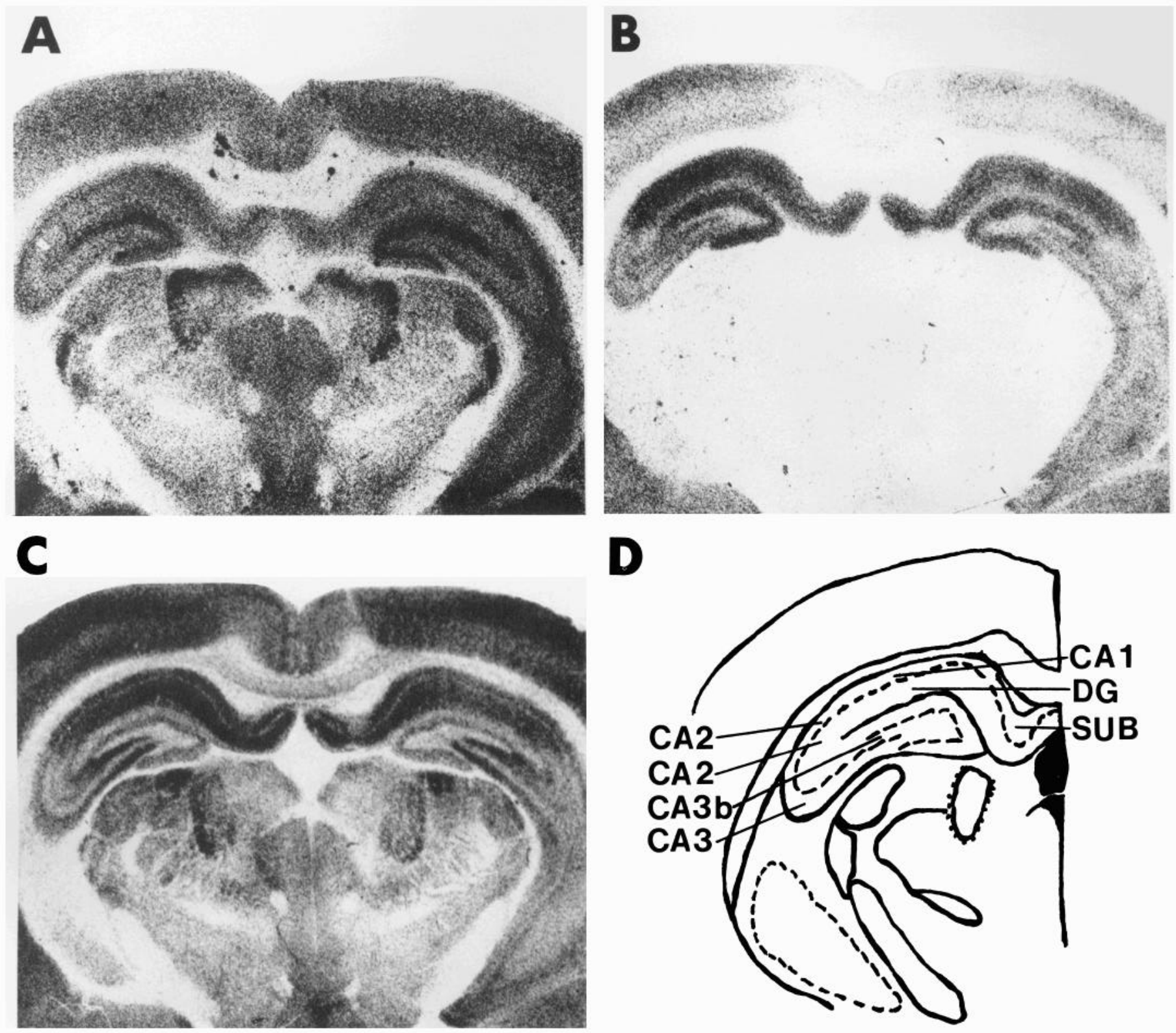

Figure 2. Distribution of choline uptake sites $(A) \mathrm{M} 1(B)$ and $\mathrm{M} 2$ receptors $(C)$ in hippocampus of unoperated control rat. $A$, Choline uptake sites labeled with ${ }^{3} \mathrm{H}-\mathrm{HC}-3 . B$, M1 receptor sites labeled with $10 \mathrm{nM} \mathrm{PZ.} C$, M2 receptor sites labeled with $1.9 \mathrm{nM}{ }^{3} \mathrm{H}-\mathrm{NMS}$ binding with M1 sites occluded with pirenzepine. $D$, Regions of hippocampus are labeled for comparison. Note the similar patterning of $\mathrm{M} 2$ receptors and ${ }^{3} \mathrm{H}-\mathrm{HC}-3$ binding in cortex and thalamic regions and the apparent inverse relationship between the density of M 2 receptors and ${ }^{3} \mathrm{H}-\mathrm{HC}-3$ density within the hippocampus.

nosum molecular layer or CA4 hilus (polymorph layer of dentate gyrus).

The histochemical demonstration of AChE staining (Fig. 1B) showed the most intense staining in the dentate gyrus and CA3, with well-defined bands of staining visible just superficial to the granule or pyramidal cell layer. The remaining layers showed a more diffuse pattern. In contrast to the ${ }^{3} \mathrm{H}-\mathrm{HC}-3$ binding, the $\mathrm{CA} 3 \mathrm{~b}$ region showed lighter AChE staining than either the CA3 or dentate gyrus regions. Also dissimilar to that of ${ }^{3} \mathrm{H}-\mathrm{HC}-3$ binding within $\mathrm{CA} 1$, the $\mathrm{AChE}$ patterning was reduced in the pyramidal layer. Moreover, the staining for AChE showed distinct bands and the lacunosum molecular layer exhibited much less intense staining than the molecular layer.

The bilateral cholinergic deafferentation and successful uni- lateral innervation by septal grafts was evident from the AChE staining pattern. Deafferentation removed all of the AChE staining (Fig. $3 B$ ) and the transplant-innervated side showed a welldefined pattern that was similar to that observed in nontransected (control) animals. As has been noted previously (Lewis and Cotman, 1983; Gibbs et al., 1986), the innervation by septal grafts was more extensive than that by striatal grafts. In the case of the striatal transplant, successful innervation occurred only when the graft was placed within the hippocampus proper (see Fig. 9D). However, innervation from such striatal transplants exhibited a pattern that was similar to, but less dense than, that observed with septal transplants. Innervation by septal transplants was more consistent and occurred when placed adjacent to the hippocampus or within the hippocampus (Fig. 3). 

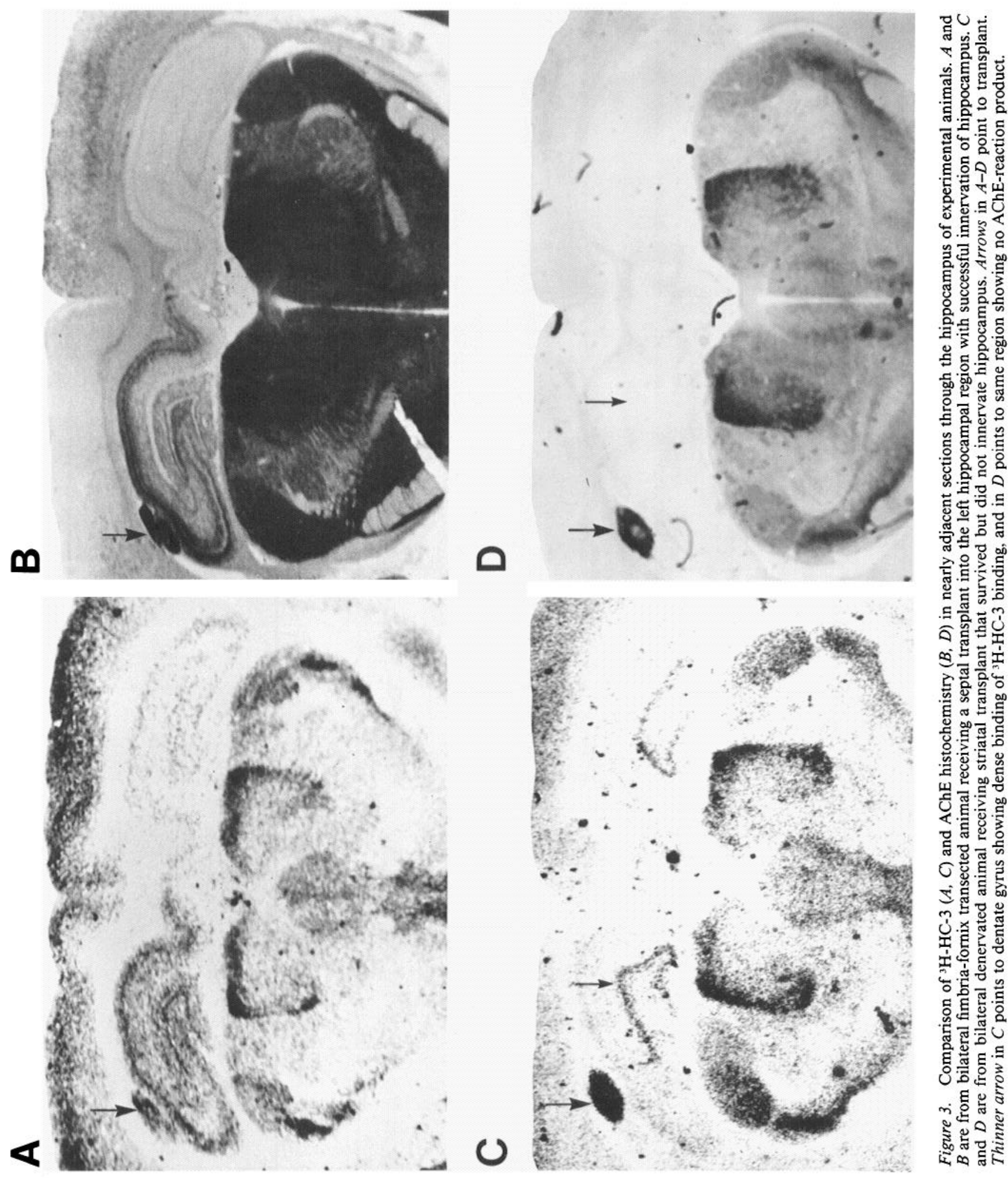


\section{(3H) HC-3 Binding Density}

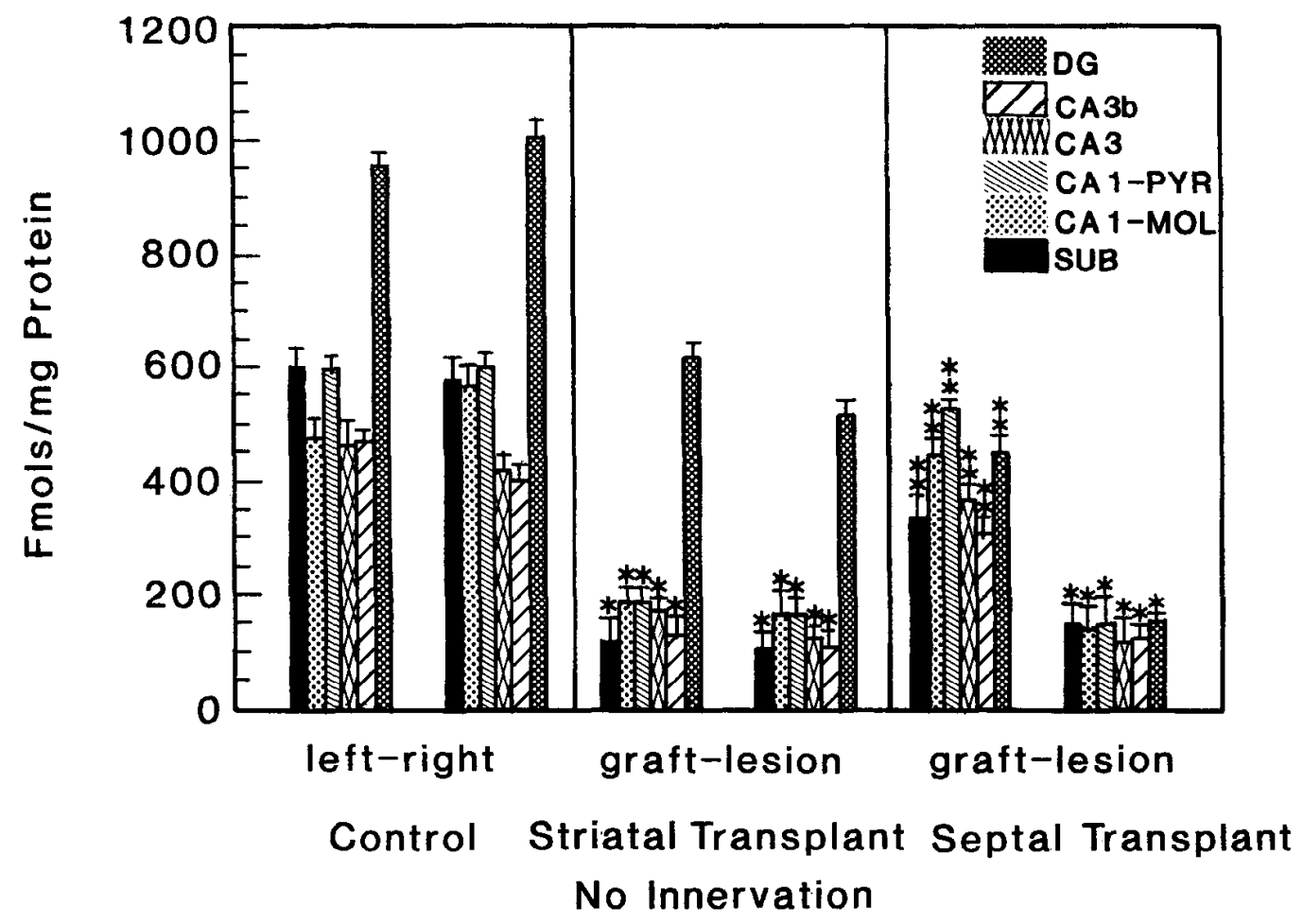

Figure 4. Bar graph showing density (fmol/mg protein) of ${ }^{3} \mathrm{H}-\mathrm{HC}-3$ binding (mean $\pm \mathrm{SEM}$ ) in subregions of the hippocampus of the left and right sides of the control animals (Controh), grafted and lesioned sides of the animals receiving striatal transplants that did not result in innervation of the hippocampus (Striatal Transplant), and grafted and lesioned sides of animals receiving successful septal transplants (Septal Transplant) that did provide innervation to the hippocampus as assessed by AChE histochemistry. Bilateral fimbria-fornix transection resulted in a significant $(p$ $<0.05$, indicated by asterisk) decline of ${ }^{3} \mathrm{H}-\mathrm{HC}-3$ binding in all subfields of the hippocampus (as compared with Controls) in animals receiving striatal transplants that showed no innervation in the hippocampus. Unilateral grafts of seplal tissue resulting in innervation of the hippocampus showed binding significantly greater than the nongraft side (lesion; ${ }^{*} p<0.05$ ) but also significantly less than the control cases $(* * p<0.05$ ). $D G$, dentate gyrus; $C A 3 b$, medial region of CA3; CA3, outer limb of CA3; CAI-PYR, pyramidal layer of CA1; CAI-MOL, lacunosum molecular layer of CAl; $S U B$, subiculum.

In the transplant-innervated hippocampus (Fig. 3, $A, B$ ), the correspondence between the AChE staining and ${ }^{3} \mathrm{H}-\mathrm{HC}-3$ binding is evident, with the denervated side exhibiting $60-80 \%$ less ${ }^{3} \mathrm{H}-\mathrm{HC}-3$ binding, depending on the region examined (Fig. 4), than the innervated side did. Thus, as indicated in Figure 4, the nongrafted side of bilaterally lesioned rats showed significantly less ${ }^{3} \mathrm{H}-\mathrm{HC}-3$ binding in all subfields of the hippocampus. The grafted side of animals with innervation to the hippocampus, as assessed by AChE staining, exhibited ${ }^{3} \mathrm{H}-\mathrm{HC}-3$ binding that was significantly greater than the nongraft side and of animals without innervation of the hippocampus but also significantly less than the control cases $(p<0.05)$. However, important contrasts are also apparent for the 2 markers. First, the ${ }^{3} \mathrm{H}-\mathrm{HC}-3$ binding in the hippocampus appears to show less of a difference between the innervated and noninnervated sides than does the AChE staining observed in adjacent sections. Second, the AChE staining was richest in regions nearest the transplant; thus, in Figure $3 B$, regions $C A 1$ and $C A 3$ are darkest with clear demarcation of the pyramidal cell layer. The medial aspects of the $\mathrm{CA} 1$, the $\mathrm{CA} 3 \mathrm{~b}$, and dentate gyrus regions show more diffuse and lighter staining than the $\mathrm{CA} 1$ region. In contrast the nearly adjacent section processed for ${ }^{3} \mathrm{H}-\mathrm{HC}-3$ autoradiography (Fig. $3 A$ ) shows nearly equivalent binding in the pyramidal layer of $\mathrm{CA} 1$ and granule layer of the dentate gyrus; and the pyramidal layer is not visible in $\mathrm{CA} 2, \mathrm{CA} 3$, and $\mathrm{CA} 4$ regions. Third, while differences in the density of ${ }^{3} \mathrm{H}-\mathrm{HC}-3$ sites exist between regions CA1-CA3b of the hippocampus, they appear to be less apparent than when observed in the AChE-stained sections. These contrasts between ${ }^{3} \mathrm{H}-\mathrm{HC}-3$ binding and AChE staining is not simply due to differences inherent with comparison of histochemical staining with autoradiography for these sites since such comparisons are highly reliable in striatum (see Rhodes et al., 1987).

Differences that exist between the pattern exhibited by ${ }^{3} \mathrm{H}-$ HC-3 binding and AChE histochemistry on the innervated side may reflect intrinsic ${ }^{3} \mathrm{H}-\mathrm{HC}-3$ binding. This is suggested by the observation that, in hippocampus where grafts did not produce significant cholinergic innervation as assessed by $\mathrm{AChE}$ staining, the dentate gyrus region shows significant ${ }^{3} \mathrm{H}-\mathrm{HC}-3$ binding without significant binding in other regions (Figs. $3, C, D ; 4$ ). What is unusual, however, is that no significant ${ }^{3} \mathrm{H}-\mathrm{HC}-3$ binding was observed in the DG opposite to that reinnervated by a transplant (Figs. 3, $A, B$; 4), whereas in the absence of reinnervation (Figs. 3, $C, D$; 4), elevated ${ }^{3} \mathrm{H}-\mathrm{HC}-3$ binding was observed in the DG on both sides.

\section{Distribution of $M 1$ and $M 2$ sites in control hippocampus}

The autoradiographic distribution of $\mathrm{Ml}$ sites utilizing $\mathrm{P} Z$ (Fig. $1 A$ ) or ${ }^{3} \mathrm{H}-\mathrm{NMS}$ with $\mathrm{M} 2$ sites masked by carbachol (Fig. $5 A$ ) 

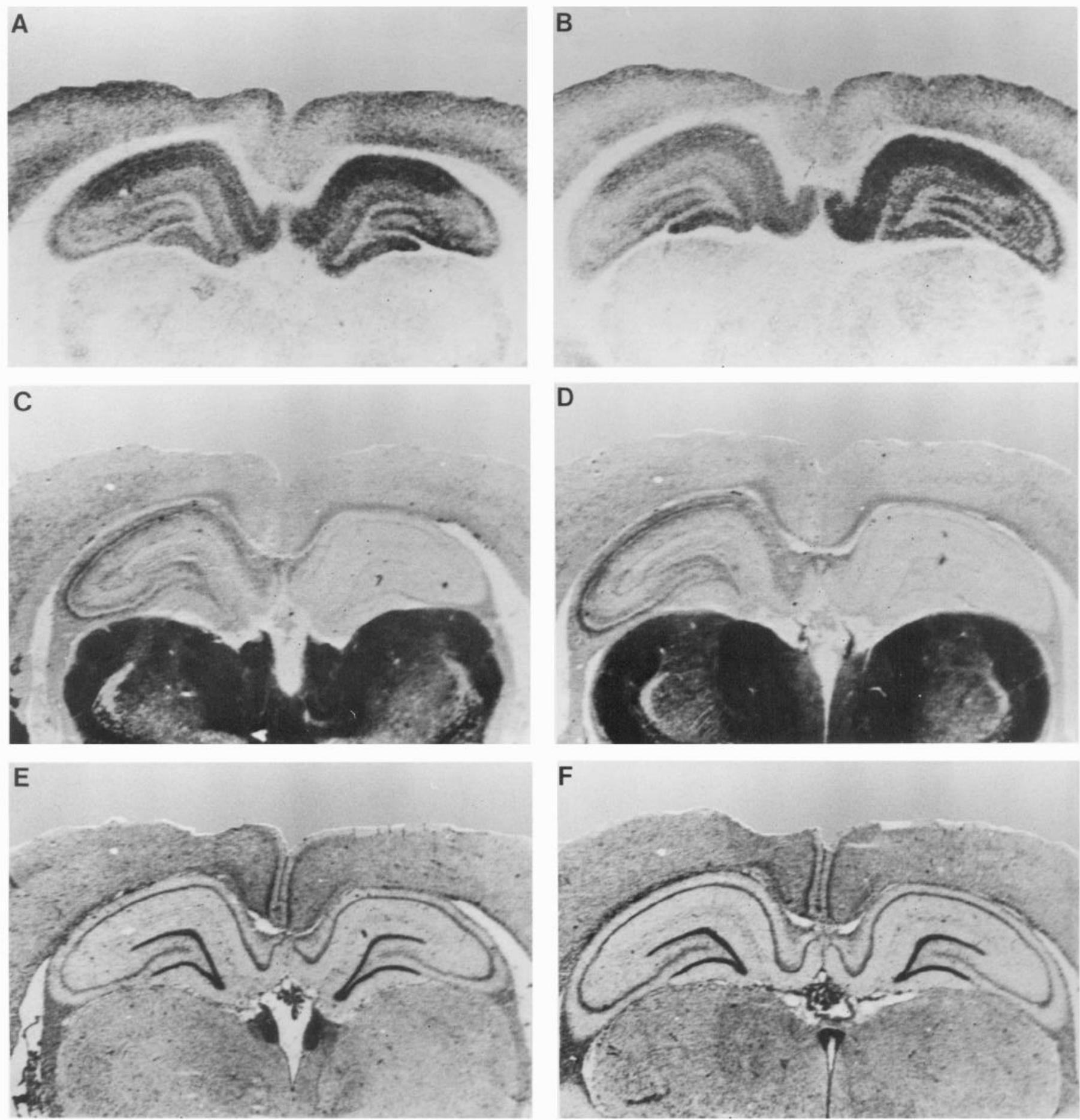

Figure 5. Effects of bilateral cholinergic denervation and unilateral reinnervation of the hippocampus on M1 receptors as seen in 2 separate animals. The side of the septal transplant is shown at left in panel, and the denervated side at right. $A$ and $B$, Density of M1 receptors $\left({ }^{3} \mathrm{H}-\mathrm{NMS}\right.$ with M2 sites occluded with carbachol) is higher on the denervated side than the side of the transplant originating cholinergic innervation. $C$ and $D$, Nearly adjacent sections to $A$ and $B$ with the AChE histochemical demonstration of the extent and pattern of cholinergic innervation from the septal transplant (section is caudal to the actual site of the transplant). $E$ and $F$, Same sections as $A$ and $B$ but stained for thionin to show regions of hippocampus.

were similar in the control (unoperated) hippocampus. With either method comparison with the adjacent section stained for AChE activity revealed a striking inverse relationship between AChE staining intensity and muscarinic M1 receptor density. Thus, the pyramidal cell layers of CA1-CA3 and the granule cell layer of the dentate gyrus showed the highest $\mathrm{AChE}$ intensity and lowest M1 receptor density (Fig. $1, A, B$ ). In contrast, the lacunosum molecular layer and the molecular layer of the dentate gyrus showed denser muscarinic receptor density and relatively lower AChE staining. The relative order of M1 receptor density within the hippocampus was lacunosum molecular layer of $\mathrm{CA} 1>$ dentate gyrus molecular layer $\gg \mathrm{CA} 3 \mathrm{~b}>$ lacunosum 


\section{M1 Receptor Density}

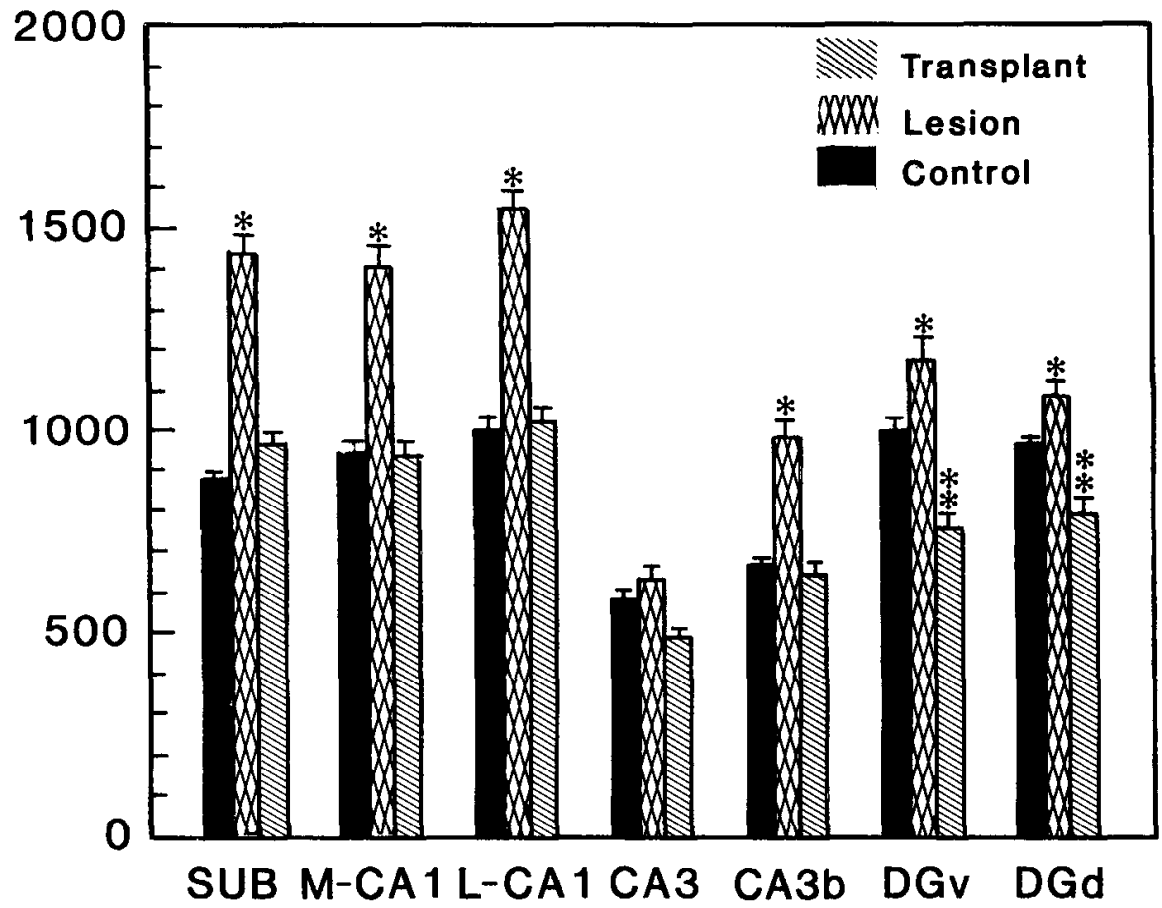

M2 Receptor Density

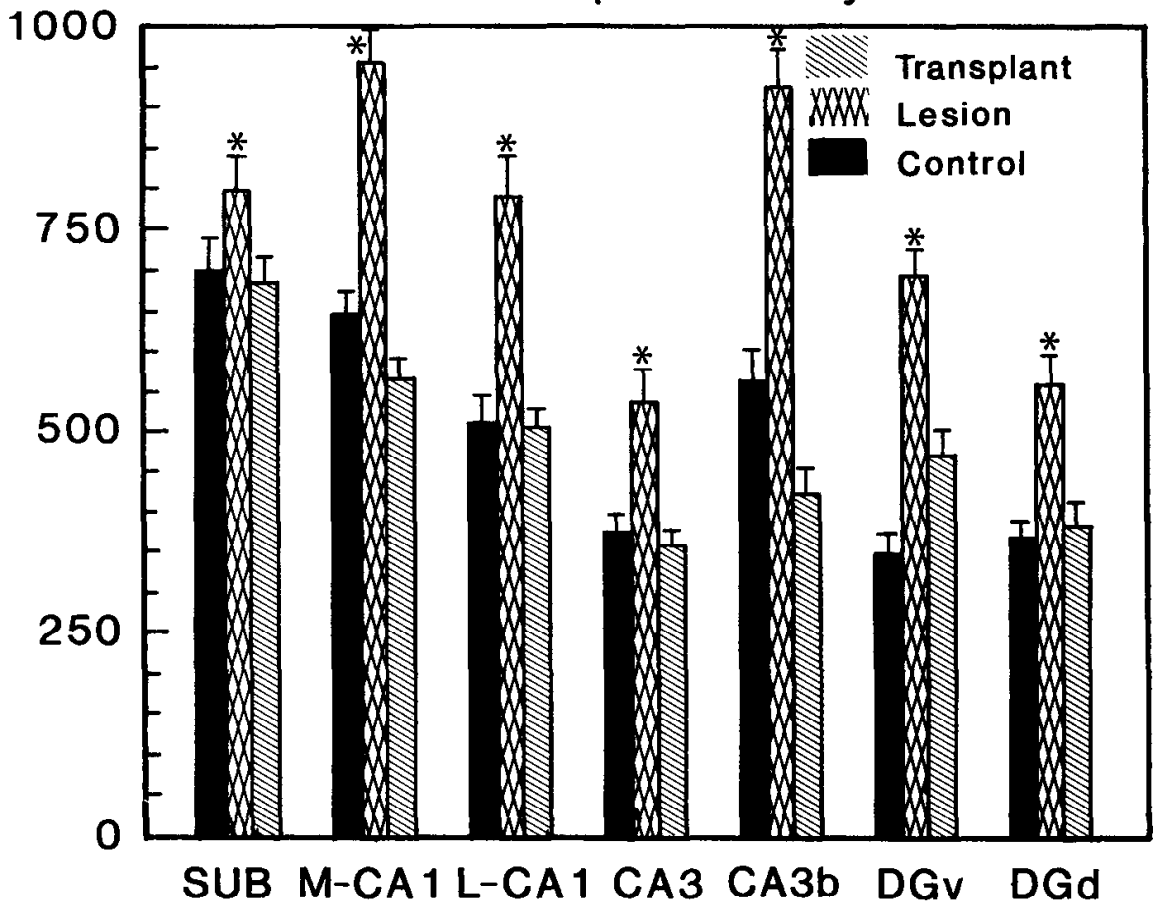

Figure 6. Bar graphs showing the density (fmol/mg protein) of $\mathrm{M} 1$ receptors (upper) and $\mathrm{M} 2$ receptors (lower) within subregions of septal transplant-reinnervated (Transplant), denervated (Lesion), and control (Control) hippocampus (mean \pm SEM). Top, Cholinergic denervation of the hippocampus following fimbria-fornix transection resulted in a significant increase in Ml receptor density in all hippocampal subfields except CA3. Septal transplants produced cholinergic innervation to hippocampus and a decrease in M1 density to control levels except in the dentate gyrus, where levels were lower than controls $\left({ }^{* *} p<0.05\right)$. Bottom, Cholinergic denervation of the hippocampus following fimbria-fornix transection resulted in a significant increase in $\mathrm{M} 2$ receptor density in all hippocampal subfields. Septal transplants produced cholinergic innervation to hippocampus and a decrease in M2 density to control levels. Asterisk indicates significant difference from control and transplant, $p<0.05$ ). The density of sites represented in the bar graph are from radioligand concentrations that are approximately one-half the $K_{d}$ for PZ binding to M1 (top) sites and 4-5 times that for ${ }^{3} \mathrm{H}$-NMS to $\mathrm{M} 2$ sites (bottom). Consequently, the density of $\mathrm{Ml}$ and M2 receptors cannot be directly compared, but the relative order within the subregions of the hippocampus accurately reflects the values determined from Scatchard analysis. For control M1 receptor density, $\mathrm{CA} 3$ and $\mathrm{CA} 3 \mathrm{~b}$ are significantly less than all other subfields. For control $\mathrm{M} 2$ receptor density: (1) CA3 and DG significantly less than all other subfields; (2) L-CA1 significantly less than $C A 3 b, M-C A 1$, and SUB. $S U B$, subiculum; $M-C A 1$, medial region of $C A 1 ; L-C A 1$, lateral region of CA1; $C A 3$, outer limb of $C A 3 ; C A 3 b$, medial region of $\mathrm{CA} 3 ; D G v$, ventral blade of the dentate gyrus; $D G d$, dorsal blade of dentate gyrus. molecular layer of $\mathrm{CA} 2 / \mathrm{CA} 3>$ hilus of $\mathrm{CA} 4$ (Fig. 1A). The exact inverse for $\mathrm{AChE}$ staining intensity was evident.

To compare the distribution of $\mathrm{M} 1$ receptors (PZ) with M2 receptors ( ${ }^{3} \mathrm{H}-\mathrm{NMS}$ with $\mathrm{M} 1$ sites masked by pirenzepine) with- in the hippocampus, serial sections from 4 unilateral transplants and 2 controls were used. In control (unoperated) rats, the distribution of $M 1$ and $M 2$ receptors showed little overlap in the cortex and thalamic regions but less distinct differences in the 


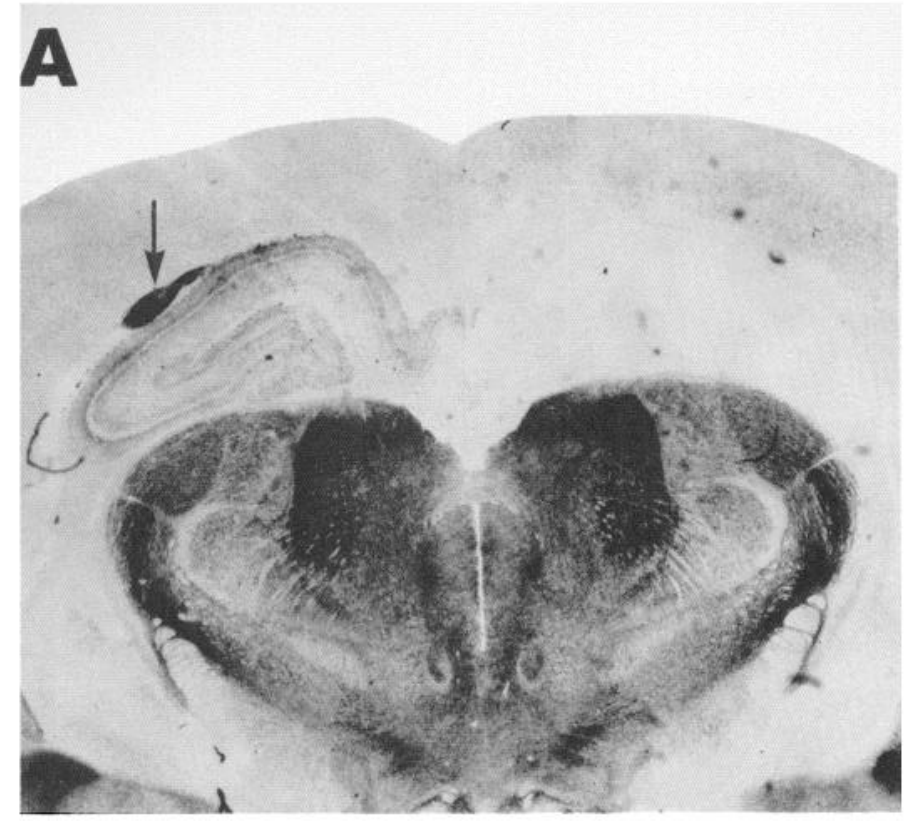

\section{B}
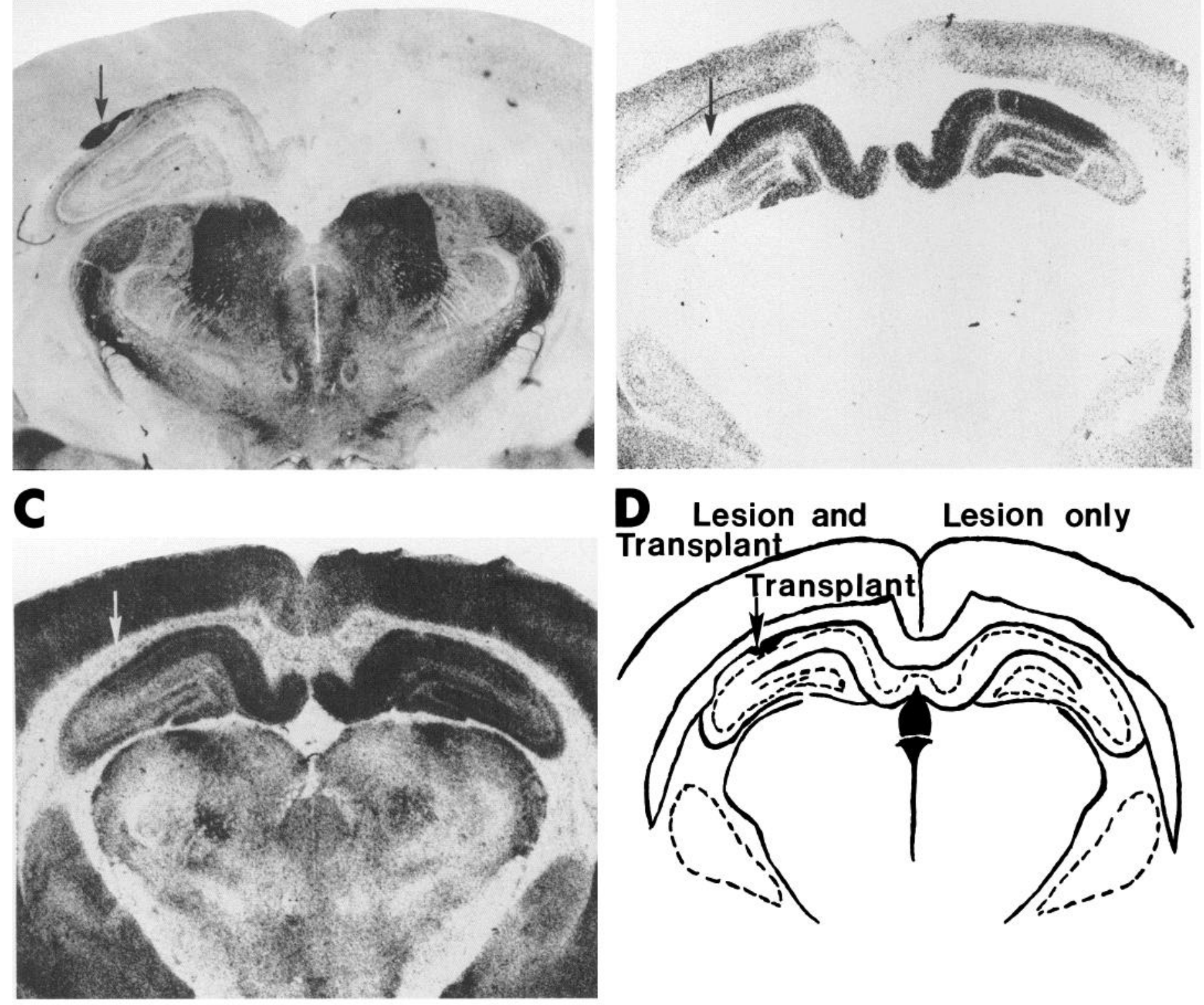

Figure 7. Effects of bilateral cholinergic denervation and unilateral reinnervation of the hippocampus on regulation of M1 and M2 receptors within the hippocampus. $A, \mathrm{AChE}$ histochemical demonstration of the septal transplant originating innervation of the hippocampus in a section nearly adjacent to $B$ and $C$. $B$, Density of M1 receptors (PZ) is greater on the denervated (right) than the reinnervated (left) side. $C$, Density of M2 receptors ( ${ }^{3} \mathrm{H}-\mathrm{NMS}$ with M1 sites occluded with pirenzepine) is greater on the denervated (right) than the reinnervated (left) side. $D$, Delineation of the hippocampus with position of transplant noted. Note that pattern of both M1 and M2 sites looks very similar to that of control hippocampus (Fig. 2) on the reinnervated side. Arrows point to transplant.

hippocampus (Figs. $1 A ; 2, B, C$ ). The density of receptor sites represented in Figure 6 and in the photos of Figures 1 and 2 were achieved using concentrations of radioligands that are approximately one-half the $K_{d}$ for PZ binding to Ml sites and 45 times that for ${ }^{3} \mathrm{H}-\mathrm{NMS}$ to $\mathrm{M} 2$ sites. Consequently, the values in Figure 6 (top and bottom) cannot be directly compared. However, Scatchard analysis indicates that within the hippocampus the $\mathrm{M} 1$ receptor density is approximately 5 -fold higher than the M2 receptor density. The photomicrographs in Figure 2 and the bar graph representation of the data in Figure 6 do present an accurate picture of the differences in relative densities within the regions of the hippocampus. In Figure 2, it can be seen that within the cortical and thalamic regions the density of M2 sites correlates highly with the density of AChE staining. Within subregions of the hippocampus there is, like for that of M1 receptors, an inverse correlation between $\mathrm{M} 2$ receptor density and density of cholinergic terminals (Fig. 2). However, important differences exist between the regional distribution of M1 and M2 sites and their relationship to ${ }^{3} \mathrm{H}-\mathrm{HC}-3$ binding, particularly within the subiculum-CA1 complex, CA4, and dentate gyrus regions. The density of $\mathrm{M} 1$ receptors is nearly uniform in the mediolateral axis from the subiculum through CA1 to the interruption in density at border of the CA2 region (Figs. 1, 2B, 6). In contrast, the density of $\mathrm{M} 2$ receptors was greatest in the 


\section{M1 Receptor Density}

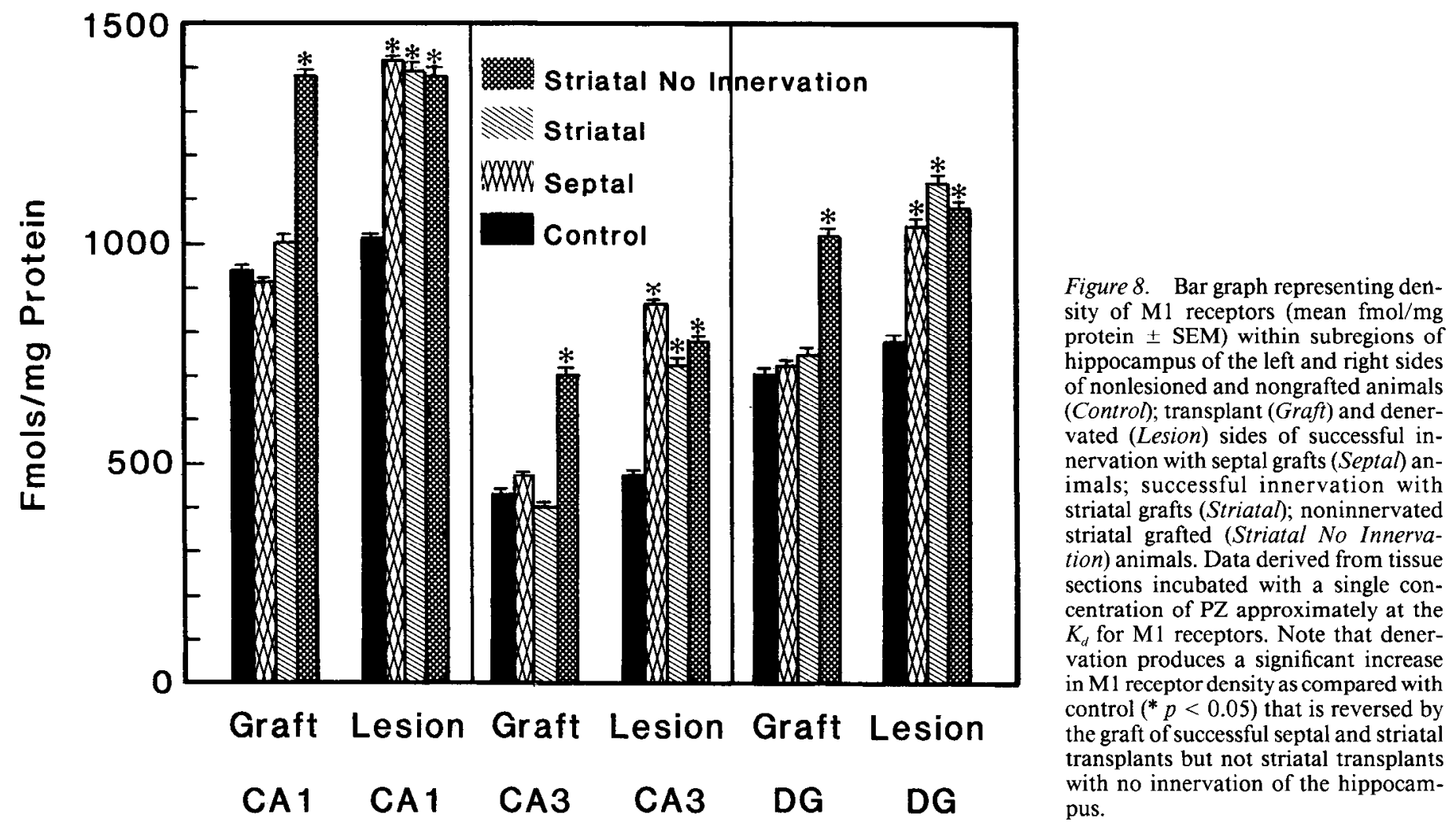

subiculum and decreased in the mediolateral axis towards CA2 (Figs. $2 C, 6$ ). Also apparent is the nearly equivalent density of $\mathrm{M} 1$ sites in the CA1 and dentate gyrus, whereas for M2 sites the dentate gyrus was relatively low in density compared with the CA1 region (Figs. 2,8). Thus, the relative order of the density of $\mathrm{M} 1$ sites was subiculum $=\mathrm{CA} 1>\mathrm{DG}>\mathrm{CA} 3 \mathrm{~b}>\mathrm{CA} 3$ (outer) $>\mathrm{CA} 2$. For comparison the relative order of the density of $\mathrm{M} 2$ sites was subiculum $>\mathrm{CAl}>\mathrm{CA} 3 \mathrm{~b} \gg \mathrm{CA} 3$ (outer) $=$ $\mathrm{DG}>\mathrm{CA} 2$. Because of this difference in relative order of the density of $\mathrm{M} 2$ and $\mathrm{M} 1$ receptors in the hippocampus, the inverse relationship between the density of ${ }^{3} \mathrm{H}-\mathrm{HC}-3$ binding and $\mathrm{M} 2$ receptors is more apparent than for $\mathrm{M} 1$ receptors.

\section{Regulation of $M 1$ and $M 2$ sites by denervation and transplant innervation}

Loss of cholinergic innervation following fimbria-fornix transection produced an increase in $\mathrm{M} 1$ receptor density that was reduced to control levels following cholinergic reinnervation by the AChE-positive fibers originating from the septal transplant (Fig. 5). The density of M1 sites labeled with a single concentration of ${ }^{3} \mathrm{H}-\mathrm{NMS}$ (in the presence of excess carbachol to mask M2 sites) was significantly $(p<0.05)$ lower on the transplant innervated hippocampus ( $30 \mathrm{~d}$ postoperatively) than on the denervated side by an average of $35 \%$, as examined in 10 sections from each of 4 septal graft-treated rats. The differences between the transplant-innervated and denervated sides was significantly greater $(p<0.05)$ for the CAl region $(47 \%)$ than for the dentate gyrus $(30 \%)$. The CA2 and CA3 regions showed intermediate reductions of 39 and $34 \%$, respectively, on the innervated side. In an additional group of animals receiving unilateral grafts and allowed to survive for $50 \mathrm{~d}$ postoperatively ( 4 septal graft, 4 striatal graft) and 2 control animals, the 2 methods for labeling of $\mathrm{M} 1$ receptor sites were compared using $\mathrm{PZ}$ or ${ }^{3} \mathrm{H}-\mathrm{NMS}$, in the presence of excess carbachol to mask M2 sites. The regulation of these sites by cholinergic graft-associated innervation was substantially the same, providing further evidence that both radioligands were labeling the $\mathrm{M} 1$ receptor under the conditions employed (Fig. 5, $A, B ; 6 ; 7$ ). The density of $\mathrm{PZ}$ binding to $\mathrm{M} 1$ receptors in the septal transplant innervated side ranged from $31-46 \%(p<0.05)$ of the noninnervated side and was indistinguishably different from the control hippocampus (Figs. 6, 7). Scatchard analysis indicated that the Ml receptors in the innervated and noninnervated sides showed no difference in affinity for $\mathrm{PZ}$, but there was a change in $B_{\max }$. The $K_{d}$ for $\mathrm{PZ}$ in the innervated side for the $\mathrm{CA} 1$ and $\mathrm{CA} 3$ regions was $26 \mathrm{~nm}$ and in the dentate gyrus was $17 \mathrm{~nm}$; in the noninnervated side, the $K_{d}$ values were 24 (CAl), 23 (CA3), and 17 nM (dentate gyrus). The $B_{\max }$ for CAl of the innervated side was $3290 \mathrm{fmol} /$ mg protein, which is significantly different $(p<0.05)$ from that of the CA3 (1819 fmol/mg protein) and the dentate gyrus (2140 $\mathrm{fmol} / \mathrm{mg}$ protein). The same regions of the noninnervated side showed a $B_{\max }$ of $4631 \mathrm{fmol} / \mathrm{mg}$ protein for CA1, $2692 \mathrm{fmol} /$ $\mathrm{mg}$ protein for CA3, and $2849 \mathrm{fmol} / \mathrm{mg}$ protein for the dentate gyrus. While all regions of the denervated hippocampus were significantly greater in density than corresponding regions of the grafted side $(p<0.05)$, the significant difference in density of sites between the CA1 and the other subfields was still retained.

The density of $\mathrm{M} 2$ receptors labeled with ${ }^{3} \mathrm{H}-\mathrm{NMS}$ (M1 sites masked by pirenzepine) exhibited a similar response to denervation and reinnervation as the $\mathrm{Ml}$ receptors (Figs. 6, 7C). Scatchard analysis indicated that the differences in the density of $\mathrm{M} 2$ receptors in the innervated and noninnervated sides was 

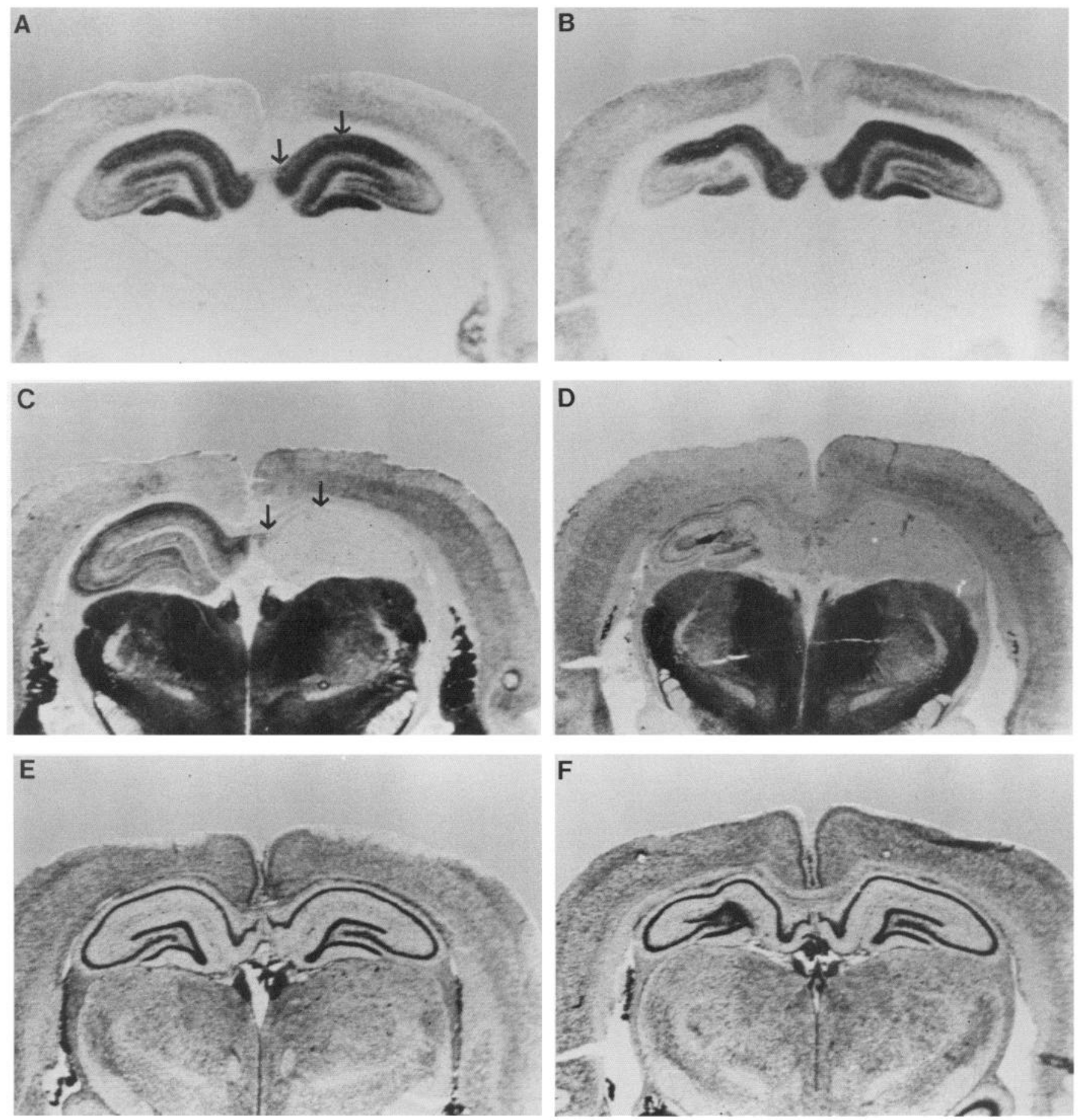

Figure 9. Relationship of M1 receptor regulation to cholinergic reinnervation of hippocampus following bilateral denervation and reinnervation from septal transplant $(A, C, E)$ or striatal $(B, D, F) . A$ and $B$, M1 receptors labeled with PZ. $C$ and $D$, AChE histochemical demonstration of transplant-originating cholinergic innervation in nearly adjacent sections. $E$ and $F$, Sections from $A$ and $B$ stained for thionin. Note in $C$ that the right hippocampus has received a small "crossover" of AChE-positive fibers (arrows) from the septal transplant into the subiculum and medial $\mathrm{CA} 1$, which has led to a reduction in M1 sites only in that region of the denervated hippocampus. Dark region near the dentate gyrus in $D$ marks striatal transplant placed into the hippocampus proper.

due to a change in $B_{\max }(p<0.05)$ with no alteration in affinity for ${ }^{3} \mathrm{H}-\mathrm{NMS}$. The $K_{d} \mathrm{~s}$ for regions CA1, CA3, and dentate gyrus of the transplant side were 260,280 , and 230 pM. For the noninnervated side, the $K_{d}$ s were 280,280 , and 240 pM for CA1, CA3, and dentate gyrus, respectively. The $B_{\max }$ for the transplant innervated side within the CA 1 region was $551 \mathrm{fmol} / \mathrm{mg}$ protein and for the noninnervated side was $910 \mathrm{fmol} / \mathrm{mg}$ protein. Similarly, that for the CA3 and dentate gyrus of the innervated side was 372 and $391 \mathrm{fmol} / \mathrm{mg}$ protein, whereas that for the noninnervated side was 530 and $603 \mathrm{fmol} / \mathrm{mg}$ protein. As shown in the photomicrographs of Figure 7 and the data in Figure 6, largely similar patterns of receptor normalization of receptor 
density occurred for both $\mathrm{M} 1$ and $\mathrm{M} 2$ receptors. For all hippocampal subfields, the denervated side showcd significantly higher binding $(p<0.05)$ than the grafted side or the same side of control animals (Fig. 6). The difference between the innervated and noninnervated side is greatest near the transplant and least where the innervation is incomplete. Thus, for example, the dorsal blade of the dentate gyrus shows denser AChE staining than the ventral blade and reduced muscarinic receptor density (Fig. 7). However, some differences in the pattern of regulation of the 2 receptor subtypes may exist. While significant differences were not achieved, the data presented in Figure 8 indicate that the medial CA1 and CA4 regions showed greater decreases in M2 receptor density than M1 receptor density on the transplant-innervated side and the subiculum showed greater reduction in the density of $\mathrm{M} 1$ receptors.

The extent and topography of the down-regulation of Ml and M2 receptors was dependent on the cholinergic reinnervation. Thus, for example, inspection of Figure 5 reveals that the ventral blade of the dentate gyrus showed less intense AChE staining from the septal-originating cholinergic innervation than did the dorsal blade, and the differences in $\mathrm{M} 1$ receptor density was less marked than for the dorsal blade. Figure $9, A, C$, shows a case where the AChE-positive fibers derived from the septal transplant crossed over to the contralateral side within the subiculum and medial CAl resulting in a reduction of the density of sites within this zone of innervation. Grafts of embryonic striatum that exhibited successful innervation of the hippocampus also resulted in a down-regulation of M1 receptors on the side of cholinergic reinnervation (Figs. 8; 9, $B, D, F$ ), and the decrease was nearly the same magnitude as that produced by septal transplantation (Figs. 5, 6). In contrast, surviving grafts of striatal tissue that did not establish cholinergic terminal innervation within the hippocampus did not induce a reduction in Ml or M2 receptor density (Fig. 8). Furthermore, transplantation of embryonic cerebellum did not show AChE-positive fiber innervation of the denervated hippocampus or down-regulation of $\mathrm{M} 1$ or $\mathrm{M} 2$ receptor density. Finally, tissue sections used for autoradiography were subsequently stained for thionin and, under $40 \times$ magnification, the width of the lacunosum molecular layer of the denervated and reinnervated side was measured. The width of the lacunosum molecular layer in the denervated and reinnervated sides showed no significant differences, indicating that changes in the density of muscarinic sites following reinnervation from septal or striatal transplants was not the result of dilution of the areas measured for receptor density.

\section{Discussion}

There has been convincing evidence from studies utilizing compounds that enhance or disrupt cholinergic transmission in the brain that the density of muscarinic receptors is regulated by the amount of ACh available at the synapse (Gazit et al., 1979; Ben-Barak and Dudai, 1980; Ehlert et al., 1980; Sutin et al., 1986). However, denervation of cholinergic synapses has not, with the exception of 2 reports (Westlind et al., 1981; McKinney and Coyle, 1982), been shown to result in increased density of muscarinic receptors (Yamamura and Snyder, 1974; Overstreet et al., 1980; Kamiya et al., 1981; Mash et al., 1985; Watson et al., 1985a; Norman et al., 1986). We approached this issue by studying a model system that allows for almost complete cholinergic denervation of the region being studied and investigated the effects of reinnervation of that same region. Furthermore, we took advantage of quantitative receptor autoradiography to examine whether regionally selective regulation of muscarinic receptor subtypes occurred following denervation and reinnervation. This paper provides strong evidence that denervation and reinnervation of muscarinic synapses by cholinergic terminals can regulate the density of muscarinic receptors. Moreover, the increase in density of both muscarinic subtypes following denervation and their down-regulation following cholinergic reinnervation provide convincing evidence that the majority of M1 and M2 receptors are located postsynaptically on neurons intrinsic to the hippocampus.

\section{Correspondence between $\mathrm{AChE}$ and ${ }^{3} \mathrm{H}-\mathrm{HC}$-3 labeling of cholinergic terminals}

We utilized 2 techniques to demonstrate the patterning of cholinergic terminals in the control, denervated, and reinnervated hippocampi: the histochemical staining for $\mathrm{AChE}$ and the autoradiographic patterning of ${ }^{3} \mathrm{H}-\mathrm{HC}-3$. Histochemical staining for AChE-positive fibers has been widely used in studies of the septohippocampal pathway. There is a functional coupling between presynaptic $\mathrm{AChE}$ and high-affinity choline uptake in rat brain (Raiteri et al., 1986) and the distribution of AChE and ChAT staining patterns is largely overlapping within the hippocampus (Anderson et al., 1986; Matthews et al., 1987). The autoradiographic patterning of ${ }^{3} \mathrm{H}-\mathrm{HC}-3$ has been used as a marker for cholinergic presynaptic sites in striatum of rabbit, human, and baboon (Lowenstein et al., 1987; Rhodes et al., 1987) and in the striatum and hippocampus of the rat (Quirion, 1985; Vickroy et al., 1985a; Manaker et al., 1986). HC-3 is a potent inhibitor of sodium-dependent high-affinity choline uptake, and ${ }^{3} \mathrm{H}-\mathrm{HC}-3$ binding labels a membrane component distributed over cholinergic cell bodies, dendrites, axons, and terminals (Vickroy et al., 1984; Sandberg and Coyle, 1985; Coyle et al., 1986). The autoradiographic distribution of ${ }^{3} \mathrm{H}-\mathrm{HC}-3$ binding correlates significantly with the immunocytochemical distribution of choline acetyltransferase (ChAT) (Levey et al., 1983; Vickroy et al., 1985b; Coyle et al., 1986; Hallanger et al., 1986). A close correlation between decreases in ChAT and ${ }^{3} \mathrm{H}$ HC-3 binding has been demonstrated following lesions of the septohippocampal pathway or the basal forebrain-cortical pathway (Sandberg and Coyle, 1985; Vickroy et al., 1985b; Watson et al., 1985a; Manaker et al., 1986; Motohashi et al., 1986).

Based on that evidence, it would be expected that the distribution of AChE-reaction product and ${ }^{3} \mathrm{H}-\mathrm{HC}-3$ binding should overlap and provide information about the extent of denervation and reinnervation of the hippocampus. In the control hippocampus, the correspondence between AChE histochemistry and ${ }^{3} \mathrm{H}-\mathrm{HC}-3$ autoradiography was close. As expected, fimbriafornix transections resulted in a major reduction of both markers in all regions of the hippocampus except the dentate gyrus. Within the hippocampus proper, the loss of ${ }^{3} \mathrm{H}-\mathrm{HC}-3$ following the fimbria-fornix transection was as much as $80 \%$, suggesting that the fimbria-fornix transection did remove the majority of cholinergic input to the hippocampus. Reinnervation of the hippocampus by the septal or striatal transplants could be visualized by both markers, and fibers from the septal transplant exhibited levels of ${ }^{3} \mathrm{H}-\mathrm{HC}-3$ binding that were $80 \%$ of control levcls. However, we did note differences between AChE histochemistry and ${ }^{3} \mathrm{H}-\mathrm{HC}-3$ binding in both the control and denervated hippocampi, particularly in the dentate gyrus. As has been reported previously (Quirion, 1985; Vickroy et al., 1985a; Manaker et al., 1986), there is dense binding of ${ }^{3} \mathrm{H}-\mathrm{HC}-3$ in the molecular layer of the dentate gyrus. We report here that this 
binding may not be correlated with AChE histochemistry. This is particularly evident following removal of extrinsic cholinergic terminals by fimbria-fornix transection, which reduced ${ }^{3} \mathrm{H}-\mathrm{HC}-3$ binding by less than $50 \%$ in the dentate gyrus but entirely removed the staining for AChE. It is unlikely that the fimbriafornix transection failed to eliminate the septal originating cholinergic fibers from the anterior (dorsal) hippocampus or that the AChE histochemistry was misleading in this regard. Similar lesions result in almost total removal of extrinsic ChAT-immunoreactive terminals (Anderson et al., 1986; Matthews et al., 1987). It is important to note in this regard that other investigators have reported that transection of the fornix produced only $80 \%$ loss of $\mathrm{ChAT}$ and ${ }^{3} \mathrm{H}-\mathrm{HC}-3$ in hippocampus (Kromer et al., 1981; Sandberg and Coyle, 1985) but complete loss of AChE activity (Kromer et al., 1981). It is possible that our failure to find complete loss of ${ }^{3} \mathrm{H}-\mathrm{HC}-3$ binding in hippocampus following transection of the fimbria-fornix is the result of collateralization of the processes of intrinsic ChAT-immunoreactive neurons that reside in the dentate gyrus (Anderson et al., 1986; Matthews et al., 1987). However, it has been reported that ChATpositive neurons intrinsic to the hippocampus fail to hypercollateralize following fimbria-fornix transection (Blaker et al., 1988). Alternatively, cholinergic fibers traveling via the supracallosal stria that normally lightly label the dentate gyrus (Kasa, 1986) may collateralize in the denervated hippocampus. It must be pointed out, however, that for either example to explain the findings, the collaterals would have to be very AChE-poor. Our evidence also suggests that the ${ }^{3} \mathrm{H}-\mathrm{HC}-3$ binding is higher in the dentate gyrus of the noninnervated than the transplant-originating reinnervated hippocampus. It is unclear why this would be the case; it is possible that the septal transplant suppresses the collateralization of any alternate cholinergic processes in the hippocampus. The failure to visualize $\mathrm{AChE}$ in the dentate gyrus in the fimbria-fornix transected cases is consistent with other evidence indicating that $\mathrm{AChE}$ is not a perfect marker for cholinergic neurons (Houser et al., 1985; Wainer et al., 1985) and may support the view that ${ }^{3} \mathrm{H}-\mathrm{HC}-3$ may be a better marker for cholinergic processes. It might also be argued that ${ }^{3} \mathrm{H}-\mathrm{HC}-3$ is labeling a site in the dentate gyrus that is not associated with the high-affinity choline transport site. A more detailed description of ${ }^{3} \mathrm{H}-\mathrm{HC}-3$ binding and ChAT-positive terminals within the hippocampus is necessary to address this issue appropriately.

\section{Topography and localization of muscarinic $M 1$ and $M 2$ receptors}

The density and patterning of M1 and M2 receptors within the hippocampus was determined autoradiographically following labeling of $\mathrm{M} 1$ receptors with $\mathrm{PZ}$ and $\mathrm{M} 2$ receptors with ${ }^{3} \mathrm{H}$ NMS in the presence of excess pirenzepine to block M1 receptors. In some cases, the M1 receptors were labeled with ${ }^{3} \mathrm{H}-$ NMS in the presence of excess carbachol to inhibit binding to $\mathrm{M} 2$ receptors. The $K_{d}$ of $\mathrm{PZ}$ for $\mathrm{M} 1$ receptors in the hippocampus (17-26 nM) was in the range reported by other investigators using similar binding conditions (Wamsley et al., 1984; Cortes et al., 1986). The distribution of M1 receptors in the hippocampus described in this paper is in agreement with previous reports using the radioligands PZ (Wamsley et al., 1984; Quirion, 1985; Spencer et al., 1986) or ${ }^{3} \mathrm{H}$-quinuclidinyl benzilate plus sufficient carbachol to inhibit binding to M2 sites (Mash and Potter, 1986). The inconsistency of the relationship between the density of M1 receptors in subregions of the hippocampus and the density of cholinergic terminals as visualized with ${ }^{3} \mathrm{H}-\mathrm{HC}-3$ (Quirion, 1985) or AChE histochemistry (Mash and Potter, 1986) has been noted previously. It has been suggested that M1 receptors may be located distal to the cholinergic synapse and respond to diffusely released ACh (Quirion, 1985). Our results suggest otherwise, that the density of M1 sites are modulated by the presence of $\mathrm{ACh}$, the presence of cholinergic fibers "down-regulating" the density of M1 receptors. This is supported by several lines of evidence: (1) The density of M1 receptors in the hippocampus was inversely related to the density of cholinergic terminals, (2) removal of the cholinergic innervation resulted in substantially higher densities than in control hippocampi, and (3) a major reduction in the density of sites could be induced by reinnervation by transplant originating cholinergic fibers. These data are at least compatible with the hypothesis that in the hippocampus $\mathrm{M} 1$ receptors are located postsynaptic to cholinergic terminals and their density is regulated by the presence of the transmitter.

The $K_{d}$ of ${ }^{3} \mathrm{H}$-NMS for M2 sites in the hippocampus with M1 receptors occluded by excess pirenzepine $(3 \mu \mathrm{M})$ was in the range of 230-280 pM, also similar to the published values for the $K_{d}$ of ${ }^{3} \mathrm{H}-\mathrm{NMS}$ to muscarinic sites in rat brain (Wamsley et al., 1980; Lee and El-Fakahany, 1985; Cortes and Palacios, 1986). Our description of the topography of M2 receptors within the hippocampus is in broad agreement with other studies (Cortes and Palacios, 1986; Mash and Potter, 1986; Spencer et al., 1986) and shows important differences from the distribution of $\mathrm{Ml}$ receptors. Thus, for $\mathrm{M} 2$ receptors the $\mathrm{CA} 1$ and $\mathrm{CA} 4$ regions are denser than CA3 and the dentate gyrus. Moreover, the subiculum shows denser binding than more lateral regions within the CA1. For M1 receptors, the subiculum is lower in sites than the $\mathrm{CAl}$ region. The CAl region is homogeneous in the mediolateral axis, comparable in density to the dentate gyrus and higher in binding than $\mathrm{CA} 3$ or CA4.

Comparison of our autoradiographic patterning of M2 sites with that of Cortes and Palacios (1986) utilizing ${ }^{3} \mathrm{H}-\mathrm{NMS}$ shows a high degree of correlation. They show, as we have, that a clear distinction in the topography of sites exists when ${ }^{3} \mathrm{H}-\mathrm{NMS}$ is used to label M1 or M2 receptors; in the former case, the distribution of sites is remarkably similar to that of PZ. Our data compare favorably with that of other laboratories that utilized different radioligands to label M2 receptors, but important differences may also exist. Similar to our results, from the autoradiographs depicted in photographs by Mash and Potter (1986) and in those of Spencer and associates (1986), the density of sites is greater in the subiculum with a reduction in density towards the lateral CAl and far less binding in the dentate gyrus than other regions. In contrast to what we and others (Cortes and Palacios, 1986) have observed, these authors (Mash and Potter, 1986; Spencer et al., 1986) report that M2 receptor density in the CA3 region appears to be greater than that within the $\mathrm{CA} 3 \mathrm{~b}$ region, and within the CAl the stratum oriens is clearly denser than the lacunosum molecular layer. Given the significant similarities between groups in the general description of the organization of $\mathrm{M} 2$ receptors within the hippocampus, the reasons for these apparent differences are unclear. It is unlikely that ${ }^{3} \mathrm{H}-\mathrm{NMS}$ is labeling $\mathrm{M} 1$ sites under the conditions employed, since the concentration of pirenzepine used blocks more than $90 \%$ of the binding to M1 receptors. Furthermore, the topography of the binding of ${ }^{3} \mathrm{H}-\mathrm{NMS}$ under conditions favoring M1 receptor labeling is far different from the topography of $\mathrm{M} 2$ receptors. It is possible that the techniques utilized 
by other groups (Mash and Potter, 1986; Spencer et al., 1986) allows for the visualization of a subset of M2 receptors.

\section{Effects of experimental denervation and reinnervation on the regulation of muscarinic receptors}

Previous research examining the effects of experimental cholinergic denervation of the hippocampus have not reported any evidence for up-regulation of muscarinic receptors in whole hippocampus (Yamamura and Snyder, 1974; Overstreet et al., 1980; Kamiya et al., 1981). The inability to demonstrate any such denervation effects in previous studies may reflect certain methodological differences, in particular (1) incomplete loss of cholinergic input after experimental denervation, (2) differential localization of muscarinic receptor subtypes, (3) short postoperative time periods, or (4) regionally selective changes in receptor density following the denervation. Our study utilized a model that produced almost total loss of cholinergic input to a restricted region of the hippocampus (dorsal), long-term denervation (30-50 d) and a method of visualizing both receptor subtypes. The septohippocampal cholinergic system contributes fibers to the dorsal hippocampus (review, Kasa, 1986) and can be completely severed with fimbria-fornix transection (Nicoll, 1985). In contrast, lesions of the basal forebrain cholinergic system innervating the cortex produce incomplete loss of ChAT activity (McKinney and Coyle, 1982; Mash et al., 1985; Watson et al., 1985a; Norman et al., 1986), possibly contributing to the lack of evidence that cholinergic receptor up-regulation occurs as a consequence of the lesions. Our analysis was restricted to the dorsal hippocampus since it appeared that the fimbria-fornix transection produced incomplete loss of fiber input to the ventral (caudal) hippocampus and fiber innervation from the transplants did not extend into that region of hippocampus. It is therefore possible that previous negative results might have been compromised by utilizing the entire hippocampus. This view is additionally supported by the results of the one other study that did describe cholinergic receptor up-regulation following denervation (Westlind et al., 1981), where effects of denervation were examined only within the dorsal (rostral) hippocampus. Length of time after the lesion may also be a factor, since McKinney and Coyle found that shortly ( $3 \mathrm{~d}$ ) after lesions of cholinergic input to the cortex there was a drop in muscarinic receptor density but a modest increase after more than 3 weeks. However, Westlind et al. (1981) used a shorter postoperative time interval than in our study, and they were able to find an increase in the hippocampus.

Our results also suggest that subregions of the hippocampus are differentially affected by denervation. The increase in the density of $\mathrm{M} 1$ receptors following denervation was greater in the subicular-CA1 region than in the dentate gyrus or CA3CA4 regions. The increase in the density of $\mathrm{M} 2$ receptors was greatest in the CA4 and CA1 regions, less in the dentate gyrus, and least in $\mathrm{CA} 3$ and subicular regions. The reduced effect in the dentate gyrus may reflect (1) alternate intact cholinergic pathways, traveling via the supracallosal stria, that also innervate this region (Kasa, 1986), (2) local collaterals from intrinsic interneurons, or (3) noncholinergic input (Loy et al., 1980; Kohler, 1982). In fact, both noradrenergic and serotinergic fibers that innervate the hippocampus would be damaged by our fimbria-fornix transection and could contribute to the increased density of muscarinic receptors. However, since reinnervation of the hippocampus by septal or striatal grafts produced an apparent down-regulation of receptors to levels comparable to the control hippocampus, the most parsimonious explanation is that cholinergic denervation and reinnervation are sufficient for regulation of muscarinic receptors. However, our results do not preclude the contribution of noncholinergic fiber innervation originating from the transplants. Nonetheless, these data providc a strong case that synaptic regulation of muscarinic receptors occurs within the brain.

The regulation of the density of $\mathrm{M} 1$ and $\mathrm{M} 2$ receptors appeared to depend on the extent and degree of cholinergic fiber innervation of the hippocampus. This is apparent from our findings that the regions of the reinnervated side exhibit an inverse relationship between the density of AChE-reaction product and muscarinic receptor density. Further evidence that regulation is independent of the transplant itself, and dependent on cholinergic innervation, derives from 2 experimental findings: (1) grafts of embryonic striatum that exhibited AChEpositive innervation of the hippocampus resulted in a downregulation of Ml sites, and (2) surviving grafts of tissue that did not show AChE-positive fiber innervation of the denervated hippocampus (some cases of striatum or cerebellum) did not produce down-regulation of M1 or M2 receptor density.

It has been proposed that M1 sites are located postsynaptic and M2 sites located presynaptic to cholinergic synapses based on the differential distribution of M1 and M2 sites in the brain (Mash and Potter, 1986; Spencer et al., 1986), correlation with AChE-positive terminals (Mash and Potter, 1986; Spencer et al., 1986) and loss of sites in cortex after destruction of the nucleus basalis (Mash et al., 1985; Watson et al., 1985a). Our results indicate that this is not the case for the septal originating cholinergic input to the hippocampus. First, it can be demonstrated that in certain regions of the hippocampus (e.g., the dentate gyrus) a high density of M1 receptors and a low density of $\mathrm{M} 2$ receptors can be topographically related to a high density of cholinergic terminals. This is not compatible with a largely presynaptic localization of M2 receptors. Second, after longterm denervation there is an increase in the density of $\mathrm{M} 2$ sites that can be down-regulated to control levels following cholinergic reinnervation. This is similar to what we observed for the regulation of $\mathrm{M} 1$ receptors. These data are more consistent with a largely postsynaptic location for M1 and M2 receptors. It is not unlikely, however, that a small population of both receptor subtypes are located presynaptically on certain populations of septohippocampal fibers. In this regard, it is important to note that it has been reported that both M1 and M2 receptors can be seen to be orthogradely transported in the septohippocampal fibers (Watson et al., 1983, 1986). It is possible that differences in the effects of denervation on the density of $\mathrm{M} 2$ receptors described by us and by Mash and Potter (1986) may also be due to the brain region examined and that a greater majority of M2 receptors are located on cholinergic terminals in cortex than in the hippocampus. Alternatively, some methods of labeling M2 receptors (Mash and Potter, 1986; Spencer et al., 1986) may preferentially label a subpopulation that are autoreceptors.

\section{Summary}

Our results regarding the distribution and apparent regulation of $\mathrm{M} 1$ and $\mathrm{M} 2$ receptors within the hippocampus after cholinergic denervation and reinnervation provide strong evidence that these receptors are under the control of cholinergic neurotransmitter activity. Furthermore, as evidenced by the regulation of the density of the muscarinic receptors, grafts of embryonic tissue are sources of cholinergic processes that make 
appropriate synaptic contacts. Our results are not consistent with the view that $\mathrm{M} 2$ receptors are largely presynaptically localized on cholinergic terminals. Our evidence indicates that the majority of $\mathrm{M} 1$ and $\mathrm{M} 2$ receptors are localized postsynaptically to cells within the hippocampus and respond to cholinergic denervation and reinnervation similarly.

\section{References}

Anderson, K. J., R. B. Gibbs, P. M. Salvaterra, and C. W. Cotman (1986) Ultrastructural characterization of identified cholinergic neurons transplanted to the hippocampal formation of the rat. J. Comp. Neurol. 249: 279-292.

Ben-Barak, J., and Y. Dudai (1980) Scopolamine induces an increase in muscarinic receptor level in rat hippocampus. Brain Res. 185: 309313.

Birdsall, N. J. M., A. S. V. Burgen, and E. C. Hulme (1978) The binding of agonists to brain muscarinic receptors. Mol. Pharmacol. 14: 723-736.

Bjorklund, A., F. H. Gage, R. H. Schmidt, U. Stenevi, and S. B. Dunnett (1983) Intracerebral grafting of neuronal cell suspensions. VII. Recovery of choline acetyltransferase activity and acetylcholine synthesis in the dencrvated hippocampus rcinncrvated by scptal suspension implants. Acta Physiol. Scand. Suppl. 522: 49-58.

Blaker, S. N., D. M. Armstrong, and F. H. Gage (1988) Cholinergic neurons within the rat hippocampus: Response to fimbria-fornix transection. J. Comp. Neurol. 272: 127-138.

Clarke, D. J., F. H. Gage, and A. Bjorklund (1986) Formation of cholinergic synapses by intrahippocampal septal grafts as revealed by choline acetyltransferase immunocytochemistry. Brain Res. 369: 151162.

Cortes, R., and J. M. Palacios (1986) Muscarinic cholinergic receptor subtypes in the rat brain. I. Quantitative autoradiographic studies. Brain Res. 362: 227-238.

Cortes, R., A. Probst, H. J. Tobler, and J. M. Palacios (1986) Muscarinic cholinergic receptor subtypes in the human brain. II. Quantitative autoradiographic studics. Brain Res. 362: 239-253.

Coyle, J. T., P. R. Lowenstein, C. Hohmann, C. Kitt, D. L. Price, and E. DeSouza (1986) Visualization of cholinergic processes in the rat and monkey forebrain: $\left[{ }^{3} \mathrm{H}\right]$ hemicholinium-3 autoradiography in relation in AChE histochemistry and ChAT immunohistochemistry. Soc. Neurosci. Abstr. 16: 810.

Duncan, D. B. (1955) Multiple range and multiple F tests. Biometrics 11: $1-42$.

Dunnett, S. B., W. C. Low, S. D. Iversen, U. Stenevi, and U. Bjorklund (1982) Septal transplants restore maze learning in rats with fornixfimbria lesions. Brain Res. 251: 335-348.

Ehlert, F. J., N. Koka, and A. S. Fairhurst (1980) Altered $\left[{ }^{3} \mathrm{H}\right]$ quinuclidinyl benzilate in the striatum of rats following chronic cholinesterase inhibition with diisopropylfluorophosphate. Mol. Pharmacol. 17: 24-30.

Gage, F. H., and A. Bjorklund (1986) Cholinergic septal grafts into the hippocampal formation improve spatial learning and memory in aged rats by an atropine-sensitive mechanism. J. Neurosci. 6: 28372847.

Gazit, H., I. Sillman, and Y. Dudai (1979) Administration of an organophosphate causes a decrease in muscarinic receptor levels in rat brain. Brain Res. 174: 351-356.

Gibbs, R. B., and C. W. Cotman (1987) Factors affecting survival and outgrowth from transplants of entorhinal cortex. Neuroscience 21 : 699-706.

Gibbs, R. B., K. Anderson, and C. W. Cotman (1986) Factors affecting innervation in the CNS: Comparison of three cholinergic cell types transplanted to the hippocampus of adult rats. Brain Res. 383: 362366.

Gil, D. W., and B. B. Wolfe (1986) Muscarinic cholinergic receptor binding sites differentiated by their affinity for pirenzepine do not interconvert. J. Pharmacol. Exp. Ther. 237; 577-582.

Hallanger, A. E., A. I. Levey, and B. H. Wainer (1986) Choline acetyltransferase immunoreactivity in the rat thalamus. Soc. Neurosci. Abstr. 16: 571.

Houser, C. R., G. D. Crawford, P. M. Salvaterra, and J. E. Vaughn (1985) Immunocytochemical localization of choline acetyltransferase in rat cerebral cortex: A study of cholinergic neurons and synapses. J. Comp. Neurol. 324: 17-34.
Hulme, E. C., N. I. M. Birdsall, A. S. V. Burgen, and P. Mehta (1978) The binding of antagonists to brain muscarinic receptors. Mol. Pharmacol. 14: 737-750.

Kamiya, H-O., A. Rotter, and D. M. Jacobowitz (1981) Muscarinic receptor binding following cholinergic nerve lesions of the cingulate cortex and hippocampus of the rat. Brain Res. 209: 432-439.

Kasa, P. (1986) The cholinergic systems in brain and spinal cord. Prog. Neurobiol. 26: 211-272.

Kasckow, J. W., G. J. Thomas, and R. M. Herndon (1984) Performance factors in regard to impaired memory and tolerance induced by atropine sulfate. Physiol. Psychol. 12: 111-115.

Kelly, P. A. T., F. H. Gage, M. Ingvar, O. Lindvall, U. Stenevi, and A. Bjorklund (1985) Functional reactivation of the deafferented hippocampus by embryonic septal grafts as assessed by measurements of local glucose utilization. Exp. Brain Res. 58: 570-579.

Kimble, D. P., R. Bremiller, and G. Stickrod (1986) Fetal brain implants improve maze performance in hippocampal-lesioned rats. Brain Res. 363: 358-363.

Koelle, G. B., and J. S. Friedenwald (1949) A histochemical method for localizing cholinesterase activity. Proc. Soc. Exp. Biol. 70: 617622.

Kohler, C. (1982) On the serotoninergic innervation of the hippocampal region: An analysis employing immunohistochemistry and retrograde fluorescent tracing in the rat brain. In Cytochemical Methods in Neuroanatomy, S. Palay and V. Chan-Palay, eds., pp. 387-407, Liss, New York.

Kromer, L. F., A. Bjorklund, and U. Stenevi (1981) Regeneration of the septohippocampal pathways in adult rats is promoted by utilizing embryonic hippocampal implants as bridges. Brain Res. 210: 173200.

Lee, J. H., and E. E. El-Fakahany (1985) [3H]N-Methylscopolamine binding to muscarinic receptors in intact adult rat brain cell aggregates. Biochem. Pharmacol. 34: 4299-4303.

Levey, A. I., B. H. Wainer, E. J. Mufson, and M. M. Mesulam (1983) Co-localization of acetylcholinesterase and choline-acetyltransferase in the rat cerebrum. Neuroscience 9: 9-22.

Lewis, E. R., and C. W. Cotman (1983) Neurotransmitter characteristics of brain grafts: Striatal tissues form the same laminated input to the hippocampus. Neuroscience 8: 57-66.

Lewis, E. R., J. C. Mueller, and C. W. Cotman (1980) Neonatal septal implants: Development of afferent lamination in the rat dentate gyrus. Brain Res. Bull. 5: 217-221.

Low, W. C., P. R. Lewis, S. T. Bunch, S. B. Dunnett, S. R. Thomas, S. D. Iversen, A. Bjorklund, and U. Stenevi (1982) Function recovery following neural transplantation of embryonic septal nuclei in adult rats with septohippocampal lesions. Nature 300: 260-262.

Lowenstein, P. R., and J. T. Coyle (1986) Rapid regulation of $\left[{ }^{3} \mathrm{H}\right]$ hemicholinium-3 binding sites in the rat brain. Brain Res. 381: 791-794.

Lowenstein, P. R., P. A. Slesinger, H. S. Singer, L. C. Walker, M. F. Casanova, D. L. Price, and J. T. Coyle (1987) An autoradiographic study of the development of $\left[{ }^{3} \mathrm{H}\right]$ hemicholinium-3 binding sites in human and baboon basal ganglia: A marker for the sodium-dependent high affinity choline uptake system. Dev. Brain Res. 34: 291-297.

Loy, R., D. A. Koziell, J. D. Lindsey, and R. Y. Moore (1980) Noradrenergic innervation of the adult rat hippocampal formation. J. Comp. Neurol. 189: 699-710.

Luthin, G. R., and B. B. Wolfe (1984) Comparison of $\left[{ }^{3} \mathrm{H}\right]$ pirenzepine and $\left[{ }^{3} \mathrm{H}\right]$ quinuclidinyl benzilate binding to muscarinic cholinergic receptors in rat brain. J. Pharmacol. Exp. Ther. 228: 648-655.

Manaker, S., C. M. Wieczorek, and T. C. Rainbow (1986) Identification of sodium-dependent, high affinity choline uptake sites in rat brain with $\left[{ }^{3} \mathrm{H}\right]$ hemicholinium-3. J. Neurochem. 46: 483-488.

Mash, D. C., and L. T. Potter (1986) Autoradiographic localization of M1 and M2 muscarinic receptors in the rat brain. Neuroscience 19: 551-564.

Mash, D. C., D. D. Flynn, and L. T. Potter (1985) Loss of M2 receptors in the cerebral cortex in Alzheimer's disease and experimental cholinergic denervation. Science 228: 1115-1117.

Matthews, D. A., P. M. Salvaterra, G. D. Crawford, C. R. Houser, and J. E. Vaughan (1987) An immunocytochemical study of choline acetyltransferase-containing neurons and axon terminals in normal and partially deafferented hippocampal formation. Brain Res. 402: $30-43$. 
McKinney, M., and J. T. Coyle (1982) Regulation of neocortical muscarinic receptors: Effects of drug treatment and lesions. J. Neurosci. 2: 97-105.

Messer, W. S., G. J. Thomas, and W. Hoss (1987) Selectivity of pirenzepine in the central nervous system. II. Differential effects of pirenzepine and scopolamine on performance of a representational memory task. Brain Res. 407: 37-45.

Motohashi, N., A. Dubois, and B. Scatton (1986) Lesion of nucleus basalis magnocellularis decreases $\left[{ }^{3} \mathrm{H}\right.$ ]hemicholinium-3 binding (as measured by autoradiography) in the amygdala and frontal cortex of the rat. Neurosci. Lett. 71: 7-12.

Nicoll, R. A. (1985) The septo-hippocampal projection: A model cholinergic pathway. Trends Neurosci. 8: 533-536.

Nieto-Sampedro, M., E. R. Lewis, C. W. Cotman, M. Manthorpe, S. D. Skaper, G. Barbin, F. M. Longo, and S. Varon (1982) Brain injury causes a time-dependent increase in neurotrophic activity at the lesion site. Science 217:860-861.

Norman, A. B., S. N. Blaker, L. Thal, and I. Creese (1986) Effects of aging and cholinergic deafferentation on putative muscarinic cholinergic receptor subtypes in rat cerebral cortex. Neurosci. Lett. 70: 289294.

Overstreet, D. H., R. C. Speth, R. E. Hruska, F. Ehlert, Y. Dumont, and H. I. Yamamura (1980) Failure of septal lesions to alter muscarinic cholinergic or benzodiazepine binding sites in hippocampus of rat brain. Brain Res. 195: 203-207.

Quirion, R. (1985) Comparative localization of putative pre- and postsynaptic markers of muscarinic cholinergic nerve terminals in rat brain. Eur. J. Pharmacol. 111: 287-289.

Raiteri, M., M. Marchi, and A. M. Caviglia (1986) Studies on a possible functional coupling between presynaptic acetylcholinesterase and high-affinity choline uptake in the rat brain. J. Neurochem. 47: 16961699.

Rhodes, K. J., J. N. Joyce, D. W. Sapp, and J. F. Marshall (1987) $\left[{ }^{3} \mathrm{H}\right]$ Hemicholinium-3 binding to rabbit striatum: Correspondence with patchy acetylcholinesterase staining and a method for quantifying striatal compartments. Brain Res. 412: 400-404.

Sandberg, K., and J. T. Coyle (1985) Characterization of $\left[{ }^{3} \mathrm{H}\right]$ hemicholinium-3 binding associated with neuronal choline uptake sites in rat brain membranes. Brain Res. 348: 321-330.

Segal, M., A. Bjorklund, and F. H. Gage (1985) Transplanted septal neurons make viable cholinergic synapses with a host hippocampus. Brain Res. 336: 302-307.

Spencer, D. G., E. Horvath, and J. Traber (1986) Direct autoradiographic determination of M1 and M2 muscarinic acetylcholine receptor distribution in the rat brain: Relation to cholinergic nuclei and projections. Brain Res. 380: 59-68.

Sutin, E. L., P. J. Shiromani, J. R. Kelsoe, F. I. Storch, and J. C. Gillin (1986) Rapid-eye movement sleep and muscarinic receptor binding in rats are augmented during withdrawal from chronic scopolamine treatment. Life Sci. 39: 2419-2427.
Vickroy, T. W., W. R. Roeske, and H. I. Yamamura (1984) Sodiumdependent high-affinity binding of $\left[{ }^{3} \mathrm{H}\right]$ hemicholinium-3 in the rat brain: A potentially selective marker for presynaptic cholinergic sites. Life Sci. 35: 2335-2343.

Vickroy, T. W., W. R. Roeske, D. R. Gehlert, J. K. Wamsley, and H. I. Yamamura (1985a) Quantitative light microscopic autoradiography of $\left[{ }^{3} \mathrm{H}\right]$ hemicholinium-3 binding sites in the rat central nervous system: A novel biochemical marker for mapping the distribution of cholinergic nerve terminals. Brain Res. 329: 368-373.

Vickroy, T. W., M. Watson, S. M. Leventer, W. R. Roeske, I. Hanin, and H. I. Yamamura (1985b) Regional differences in ethylcholine mustard aziridinium ion (AF64A)-induced deficits in presynaptic cholinergic markers for the rat central nervous system. J. Pharmacol. Exp. Ther. 235: 577-582.

Wainer, B. H., A. J. Levey, D. B. Rye, M. M. Mesulam, and E. J. Mufson (1985) Cholinergic and non-cholinergic septo-hippocampal pathways. Neurosci. Lett. 54: 45-52.

Wamsley, J. K., M. A. Zarbin, N. J. M. Birdsall, and M. J. Kuhar (1980) Muscarinic cholinergic receptors: Autoradiographic localization of high and low affinity agonist binding sites. Brain Res. 200: 112.

Wamsley, J. K., D. R. Gehlert, W. R. Roeske, and H. I. Yamamura (1984) Muscarinic antagonist binding site heterogeneity as evidenced by autoradiography after direct labeling with $\left[{ }^{3} \mathrm{H}\right] \mathrm{QNB}$ and $\left[{ }^{3} \mathrm{H}\right]$ pirenzepine. Life Sci. 34: 1395-1402.

Watson, M., H. I. Yamamura, and W. R. Roeske (1983) A unique regulatory profile and regional distribution of $\left[{ }^{3} \mathrm{H}\right]$ pirenzepine binding in the rat provide evidence for distinct M1 and M2 muscarinic receptor subtypes. Life Sci. 32: 3001-3011.

Watson, M., T. W. Vickroy, H. C. Fibiger, W. R. Roeske, and H. I. Yamamura (1985a) Effects of bilateral ibotenate-induced lesions of the nucleus basalis magnocellularis upon selective cholinergic biochemical markers in the rat anterior cerebral cortex. Brain Res. 346: 387-391.

Watson, M., T. W. Vickroy, W. R. Roeske, and H. I. Yamamura (1985b) Functional and biochemical basis for multiple muscarinic acetylcholine receptors. Prog. Neuropsychopharm. Biol. Psychiatry 9:569-574.

Watson, M., W. R. Roeske, T. W. Vickroy, T. L. Smith, K. Akiyama, K. Gulya, S. P. Duckles, M. Serra, A. Adem, A. Nordberg, D. R. Gehlert, J. K. Wamsley, and H. I. Yamamura (1986) Biochemical and functional basis of putative muscarinic receptor subtypes and its implications. TIPS Suppl. 2: 46-55.

Westlind, A., M. Grynfarb, B. Hedlund, T. Bartfai, and K. Fuxe (198I) Muscarinic supersensitivity induced by septal lesion or chronic atropine treatment. Brain Res. 225: 131-141.

Yamamura, H. I., and S. H. Snyder (1974) Postsynaptic localization of muscarinic cholinergic receptor binding in rat hippocampus. Brain Res. 78: 320-326. 